\title{
Early sheep herd management in the inland of the Iberian Peninsula: results of the incremental isotopic analyses of dental remains from El Mirador cave (Sierra de Atapuerca, Spain)
}

\author{
Patricia Martín ${ }^{1,2,3}$ (1) C Carlos Tornero ${ }^{2,3} \cdot$ Domingo Carlos Salazar García ${ }^{4,5,6} \cdot$ Josep Maria Vergès $s^{2,3}$
}

Received: 20 July 2020 / Accepted: 23 April 2021

(C) The Author(s), under exclusive licence to Springer-Verlag GmbH Germany, part of Springer Nature 2021

\begin{abstract}
The beginning of husbandry in the Iberian Peninsula has been documented from the second half of the 6th millennium BCE and was based on the breeding of domestic caprines, mainly sheep. The first evidence of these practices comes from the Mediterranean region, but they quickly expanded inland. Previous studies have reported on the importance of the El Mirador sheepfold cave (Sierra de Atapuerca, Burgos, Spain) for understanding the process of the adoption of a farming economy in this inland region. In this study, we focus on husbandry and sheep management occurring in the 6th and 5th millennium cal BCE occupations of El Mirador cave by means of sequential oxygen $\left(\delta^{18} \mathrm{O}\right)$ and carbon $\left(\delta^{13} \mathrm{C}\right)$ isotope analyses in sheep molar tooth enamel. The results show a rapid adaptation and adoption of domestic sheep in the inland of the Iberian Peninsula. In El Mirador cave, well-organised sheep breeding was developed based on the concentration of births at the end of winter and early spring, for a period of $\sim 2.64$ months, which made husbandry more compatible with other economic activities. In 5 th millennium levels, autumn births were also documented and may be indicative of the intervention of the shepherd in the reproductive cycle of the sheep and of a progressive adaptation of these animals to the interior of the Peninsula. All these strategies may have been supported by the recurrent occupations of the sheepfold, flocks grazing in the areas surrounding the cave and the possible use of leaf fodder in winter.
\end{abstract}

Keywords Husbandry $\cdot$ Neolithic $\cdot$ Stable oxygen and carbon isotopes $\cdot$ Reproductive seasonality $\cdot$ Animal diet

Patricia Martín

patrimr9@gmail.com

1 Seminari d'Estudis i Recerques Prehistòriques (SERP), Departament d'Història i Arqueologia, Universitat de Barcelona, C/ Montalegre 6, 08001 Barcelona, Spain

2 Institut de Paleoecologia Humana i Evolució Social (IPHES-CERCA), Zona educacional 4, Campus Sescelades URV (Edifici W3), 43007 Tarragona, Spain

3 Àrea de Prehistòria, Universitat Rovira i Virgili (URV), Facultat de Lletres, Avinguda Catalunya, 35, 43002 Tarragona, Spain

4 Department of Geological Sciences, University of Cape Town, Cape Town, South Africa

5 Departament de Prehistòria, Arqueologia i Història Antiga, Universitat de València, València, Spain

6 Grupo de Investigación en Prehistoria IT-1223-19 (UPV-EHU/ IKERBASQUE-Basque Foundation for Science), Vitoria, Spain

\section{Introduction}

The oldest evidence of Neolithic occupations with agropastoral economies in the Iberian Peninsula comes from open-air sites and caves along the Mediterranean coast and date to around the mid-6th millennium cal BCE (e.g. Esquembre-Bebiá et al. 2008; Bernabeu et al. 2009; Cortés Sánchez et al. 2012; Oms et al. 2016; García-Puchol et al. 2017). Traditionally, it has been suggested that the introduction of these economic and technological innovations in inland Iberia, and specifically towards the Submeseta Norte (the northern subplateau) region, was slow, based on the scarcity of evidence and its recent chronology (5th millennium cal BCE) (Maluquer 1960; Fernández-Posse 1980). We now know that the early evidence for the Neolithic in inland Iberia can be dated to the second half of the 6th millennium BCE (e.g. Baldellou Martínez 2011; Fernández-Eraso and Mujika-Alustiza 2013; García-Martínez de Lagrán 2014; Fernández-Eraso et al. 2015; Villalba-Mouco et al. 2018). Most of these inland sites are located around the Ebro valley, 
which suggests that this river was one of the main routes of communication and diffusion of the new economic system from the coast towards the inland (Arias 2007). The presence of Cardial pottery in these sites establishes a clear link to the settlements on the coast (Baldellou Martínez 2011; Fernández-Eraso et al. 2015).

These inland communities had a fully consolidated agricultural and livestock economy that was adapted to inland climatic and environmental conditions, as these diverged from those of the Mediterranean coastal region. Currently, Mediterranean region has temperate climate ('Csa' following the Köppen climate classification), with dry summers. Inland of the Iberian Peninsula has cold and different temperate climates (with and without dry seasons) (AEMET 2011). The aforementioned Ebro Valley has a cold steppe ('BSk', following the Köppen climate classification) climate, with average annual temperatures below $18^{\circ} \mathrm{C}$ and with low rainfall levels spread throughout the year (AEMET 2011) that were higher during the 6th and 5th millennia cal BCE (Penalba 1994; Pérez-Obiol et al. 2011). Currently, it is an area of Mediterranean landscape in which open areas of scrubland predominate. Whereas, the Submeseta Norte has a temperate oceanic climate 'Cfb,' (following the Köppen climate classification), without dry season and with moderate temperatures in winter and cool in summer (less than $22^{\circ} \mathrm{C}$ average). This region is dominated by wooded vegetation (mixed forests) and scrub.

The adaptation of new domestic species to different environmental conditions of the Iberian Peninsula was particularly evident in crops. Thus, the importance of the most common species, hulled or naked wheat and barley, varied in different areas of the Peninsula, depending on environmental conditions (López et al. 2003; Zapata et al. 2004, 2005; PeñaChorarro et al. 2018).

Regarding husbandry, there is a clear predominance of domestic caprine breeding, both in coastal and inland regions, especially in cave sites (e.g. Castaños 1997; Castaños 2004; Morales and Martín 2003; Altuna and Mariezkurrena 2009; Saña 2013; Davis and Simões 2016; Saña et al. 2020). There is body size homogeneity in both coastal and inland caprine populations (Antolín et al. 2018; Sierra et al. 2019). Amongst domestic caprines, sheep outnumber goats, indicating the importance of sheep as the basis of husbandry in the Early Neolithic period in the Iberian Peninsula. These factors seem to indicate that animal species were more plastic in response to environmental variability than plants (Saña et al. 2020).

Beyond the composition of the herds, in Iberian Peninsula assemblages, there are few studies on mortality profiles that would provide information on different aspects of management and exploitation of these species. Although it is difficult to generalise, the few published zooarchaeological studies would indicate a tendency to slaughter immature animals (0-24 months) with the intention of using the meat and/or milk (Castaños 2004; Iborra and Martínez 2009; Saña 2011; Sierra et al. 2019; Tejedor-Rodríguez et al. 2021). Milk use was also documented by means of lipid residue analysis (Debono Spiteri et al. 2016; Cubas et al. 2020).

One of the most poorly understood features of Neolithic sheep management in the Iberian Peninsula is the breeding and lambing periods. Until now, only data on the Neolithic sheep in the Els Trocs cave is available (Tejedor-Rodríguez et al. 2021) where winter/spring and autumn births were documented.

In temperate latitudes, maximum sexual activity of ewes occurs in mid autumn and births occur at the end of winter or the beginning of spring, after 5-5.5 months of gestation (Hafez 1952; Jewell and Grubb 1974; Cambero 1997; Malpaux et al. 1996; Santiago-Moreno et al. 2006). This reproductive seasonality is under photoperiodic control as a response to climatic variability and the seasonal availability of resources (Dwyer 2008). But although photoperiodic control remains important, the process of domestication and/or environmental factors (e.g. temperature, nutritional status, timing of births, or social interactions), whether or not they are controlled by the herder, have contributed to modifying reproductive seasonality (e.g. Poulton and Robinson 1987; Forcada et al. 1992; Rose and Bryant 2003; Gómez-Brunet et al. 2012). Earliest pieces of evidence of this sheep lambing deseasoning in the Western Mediterranean were documented in southern France (Tornero et al. 2020) and in the already mentioned Iberian Peninsula sheep of Els Trocs cave, by means of sequential oxygen $\left(\delta^{18} \mathrm{O}\right)$ and carbon $\left(\delta^{13} \mathrm{C}\right)$ isotope analyses.

The $\delta^{18} \mathrm{O}$ values measured in sheep molars mainly come from ingested water and the consumption of plants. These $\delta^{18} \mathrm{O}$ values are in turn related to the original signatures in meteoric water. In temperate areas, $\delta^{18} \mathrm{O}$ values in meteoric water vary according to ambient temperature. In mid and high latitudes, the highest values of $\delta^{18} \mathrm{O}$ occur in the warmest months and the lowest values in the coldest months (Gat 1980). Thus, sequential series of $\delta^{18} \mathrm{O}$ values in sheep tooth enamel can provide evidence for changes in temperature means that occurred during the formation of the tooth (Bryant et al. 1996; Fricke and O’Neil 1996); although low inter-individual variability is noted during transient events (Green et al. 2017); this can be used to determine the seasonality of birth of the analysed individuals. This is an approach with great temporal precision of the isotopic signal because the period of tooth formation is very similar across individuals (Hillson 2005). Further, tooth enamel is not remodelled once formed and this tissue is less susceptible than others to diagenetic alterations during fossilization (Lee-Thorp et al. 1989; 1991; Shahack-Gross et al. 1999).

In addition, sequential series of $\delta^{18} \mathrm{O}$ values from modern sheep specimens facilitates both comparisons with our archaeological assemblages and the determination of a precise season of birth and duration of the lambing period (Balasse et al. 
2012a, 2012b; Tornero et al. 2013). These data are important, not only for understanding the management of herds but also the cycles of occupations at archaeological sites. Furthermore, the combination of these data with information regarding ageat-death and mortality profiles from sheep faunal remains can help detect seasonal occupations of the settlements.

These can be also complemented by an analysis of $\delta^{13} \mathrm{C}$ values from dental enamel, which can provide information on the diet of the sheep and herd feeding strategies. $\delta^{13} \mathrm{C}$ values are incorporated into sheep enamel from consumed plants. Plants differ on its $\delta^{13} \mathrm{C}$ values depending on whether they are classified as $\mathrm{C}_{3}$ or $\mathrm{C}_{4}$. At present, in Iberia, $\mathrm{C}_{3}$ plants (trees, shrubs, most herbaceous dicotyledonous plants and most grasses) are the most common species and $\mathrm{C}_{4}$ are residual (Mateu 1993). An average $\delta^{13} \mathrm{C}$ value of $-13 \%$ in bioapatite tooth enamel indicates that $\mathrm{C}_{3}$ were the predominant types of plants consumed by sheep (Cerling and Harris 1999; Kohn 2010).

The composition and seasonal variation of herds' diets can be estimated by investigating the covariation of both isotopic curves of $\delta^{13} \mathrm{C}$ and $\delta^{18} \mathrm{O}$ values (Balasse et al. 2002). The $\delta^{13} \mathrm{C}$ values of plants vary according to their photosynthesis strategies and environmental conditions (Bender 1971). Thus, the plants of closed areas, present more negative values of $\delta^{13} \mathrm{C}$, due to the forest depletion of ${ }^{13} \mathrm{C}$ or 'canopy effect' (van der Merwe and Medina 1991; Drucker et al. 2008; Tornero et al. 2020).

Synchronous rises and falls in $\delta^{13} \mathrm{C}$ and $\delta^{18} \mathrm{O}$ values mark a dietary seasonality in which individuals ingest ${ }^{13} \mathrm{C}$-enriched water-stressed graze in the hottest and driest months of the summer (Fraser et al. 2008). In addition, when $\delta^{13} \mathrm{C}$ values are especially depleted during specific seasons, this could be related to the use of leaf fodder from a dense forest for animal feeding (Balasse et al. 2012b).

In this paper, we present an isotopic analysis $\left(\delta^{18} \mathrm{O}\right.$ and $\delta^{13} \mathrm{C}$ ) of the sheep from the oldest Neolithic occupations of El Mirador cave.

El Mirador cave has become a paradigmatic site for understanding the adoption and development of husbandry practices in the Submeseta Norte region. Firstly, it is strategically located between the Ebro and Duero basins, along the natural communication routes that could have served to spread the Neolithic package in these areas. Secondly, the first Neolithic occupations of El Mirador date from the second half of the 6th millennium $\mathrm{BCE}$ (5210-5170 cal BCE), and are some of the oldest in inland Iberia (Vergès et al. 2016a). Thirdly, El Mirador is a sheepfold cave, where domestic caprines are abundant, being sheep the most numerous (Angelucci et al. 2009; Martín 2015; Vergès et al. 2016a). In particular, the abundance of perinatal caprines suggests that the cave was used especially as a fold for pregnant females and their offspring (Martín et al. 2016). This pattern of occupation is especially intense in older levels (6th and 5th millennia) where perinatal individuals were more abundant.
The main objective of this research is to study the reproductive seasonality and seasonal dietary patterns of sheep reared during the earliest occupations of El Mirador cave. This information will help us address the following issues of early livestock management in inland Iberia:

- the seasonality of births and the length of the lambing period;

- strategies for the supply of animal feed;

- the use of El Mirador cave in relation to husbandry practices.

\section{Archaeological context}

El Mirador cave (Sierra de Atapuerca, Burgos) is in the Submeseta Norte region of the Iberian Peninsula (Fig. 1), a wide plain with an altitude above sea level of more than 600 $\mathrm{m}$. El Mirador cave is located at 1033 m.a.s.l. Its geographical coordinates are $42^{\circ} 20^{\prime} 58^{\prime \prime} \mathrm{N}, 03^{\circ} 30^{\prime} 33^{\prime \prime} \mathrm{W}$.

The cave was mainly used as a sheepfold from the Early to Late Neolithic and during the Middle Bronze Age (Vergès et al. 2016a), although waste remains from domestic activities performed in the cave have also been documented. The faunal remains studied here come from the base levels (MIR24, MIR19, MIR16, MIR15 and MIR14) of a $6 \mathrm{~m}^{2}$ test pit sequence, dated to the 6th and 5th millennia cal BCE. Archaeologically, the use of the cave as a sheepfold is well supported by the successive sedimentary layers formed by dung and plant remains, referred to by the French term fumier (Brochier 2002; Angelucci et al. 2009). Unburned layers of dung, which accumulated during herd stabling, were alternated with layers of dung which were burned to sanitize the area. The combustion process is affected by several important variables (Vergès et al. 2016b) that generate a high complexity fumier stratigraphic sequences with vertical and lateral variability and sedimentary discontinuity (Angelucci et al. 2009; Vergès et al. 2016a).

As discussed above, a mixed crop and livestock economy was practiced at El Mirador cave site (Martín 2015; Martín et al. 2016; Rodríguez et al. 2016; Bañuls et al. 2017; Expósito et al. 2017). These two activities were documented both inside and outside the cave. Palynological analyses showed the proximity of crop fields, based on cereal production (mainly Triticum aestivum/durum and T. dicoccum) (Rodríguez et al. 2016; Expósito et al. 2017). Crop threshing took place inside the cave and was most common at the base of the sequence (MIR19-MIR24), where higher percentages of synanthropic species and parts of cereal crops were documented (e.g. rachis fragments, spikelet forks and fork fragments) (Rodríguez and Buxó 2008; Rodríguez et al. 2016).

Husbandry was focused on sheep and goats, complemented with cattle and pig. Some wild species were 


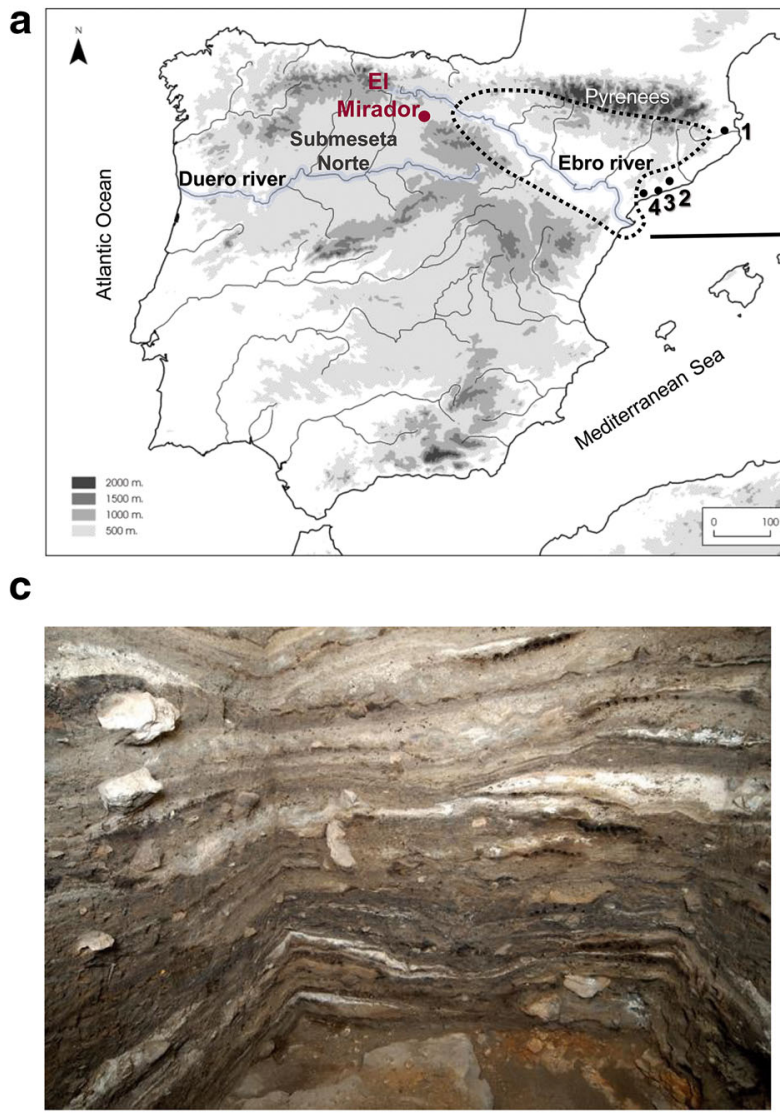

b

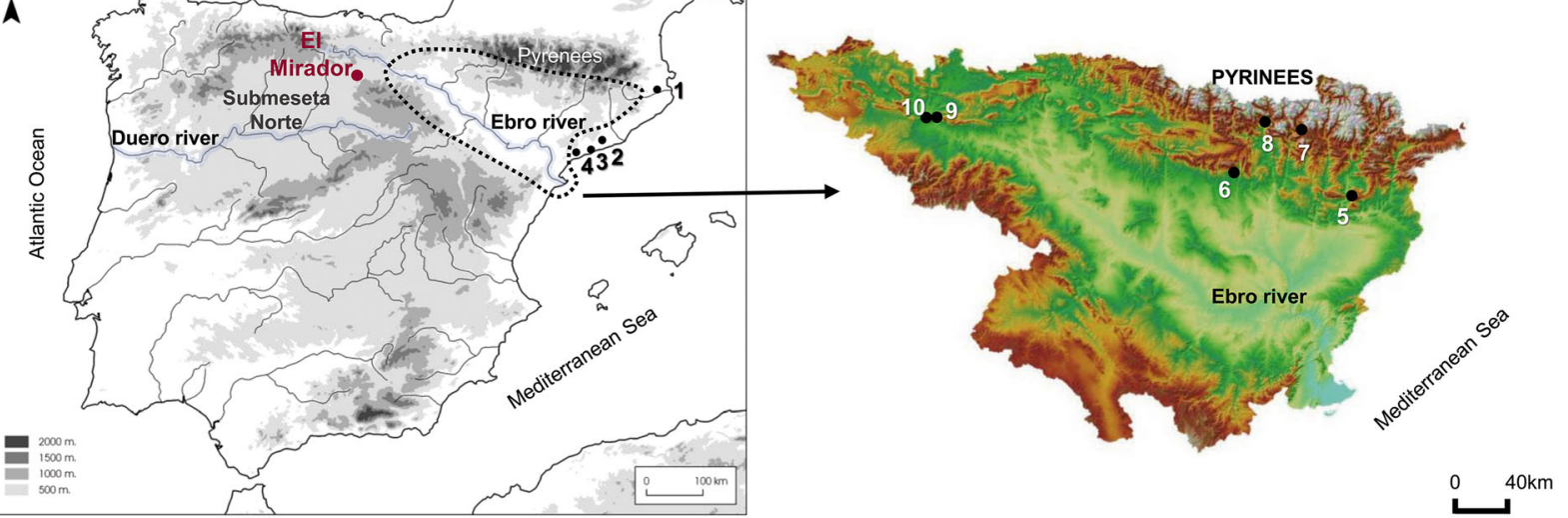

d

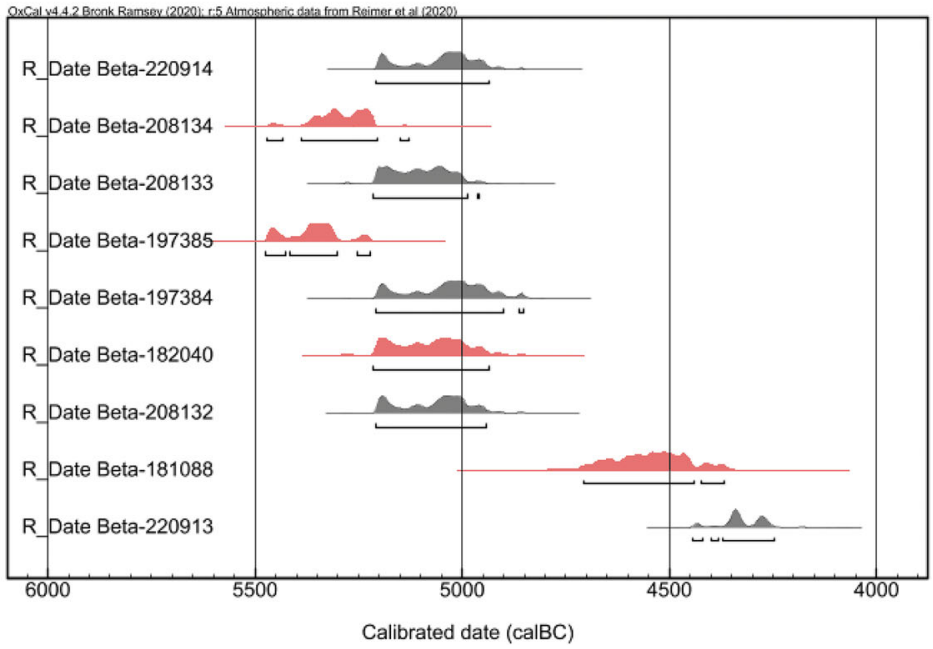

Fig. 1 Location of El Mirador cave (a) and of the main Early Neolithic of sites of the NE of the Iberian Peninsula and of the basin of the Ebro (with domestic fauna) (b). Fumier sequence of El Mirador cave (c). Radiocarbon dates (cal BC) from 6th and 5th millennium occupations of El Mirador (short-lived dates in black; long-lived dates in red) (Vergès et al. 2016a) (d). The calibration of radiocarbon dates using OxCal v.4.4.2 (Bronk Ramsey 2009, 2017). List of the Early Neolithic sites: 1. La Draga (5314-5209) (Terradas-Batlle et al. 2015); 2. Les

Guixeres de Vilobí (5660-5500/5510-5350) (Oms et al. 2014); 3. El Cavet (5740-5630) (Fontanals et al. 2008); 4. Cova de la Font Major (5390-5190) (Cebrià et al. 2014); 5. Cova Colomera (5614-5479) (Oms et al. 2013); 6. Chaves (5614-5479) (Baldellou Martínez 2011); 7. Els Trocs (5315-5215) (Rojo-Guerra et al. 2014); 8. Coro Trasito (5322-5207) (Clemente-Conte et al. 2016); 9 Peña Larga (5710-5610/ 5590-5560) (Fernández-Eraso 1989); 10. Los Husos I (5320-5040) (Fernández-Eraso and Mujika-Alustiza 2013)

also included in the diet of the people inhabiting El Mirador cave, but they were of secondary importance (Martín et al. 2009; Martín 2015; Martín et al. 2016). Amongst sheep and goats, there is a predominance of perinatal individuals (foetuses and neonates) (75-41.7\% of total sheep/goat MNI) (Fig. 2). Although the high degree of fracturing and the abundance of these perinatal individuals have made it difficult to distinguish between goat and sheep species, there is a slight predominance of sheep, especially in the Neolithic occupations (Martín 2015) (Fig. 2).

The pollen signal has also yielded information about husbandry pressure around the site, with the presence of nitrophilous plants that are common in livestock areas (e.g. Plantago spp. or Urticaceae, amongst others) (Expósito et al. 2017). These areas were composed of a vegetal mosaic of open prairies, fields and woody areas (deciduous and

evergreen oak, Fraxinus sp., Pinus Sylvestris and Corylus avellana) (Euba et al. 2016; Rodríguez et al. 2016; Expósito et al. 2017). Based on the presence of young deciduous branches or fragments of Quercus spp. in the sequence of El Mirador cave, anthracological studies point to the possibility that people used resources from woody areas to obtain fodder for the herd (Allué and Euba 2008; Euba et al. 2016).

\section{Materials and methods}

Eight M2 of Ovis aries were selected for this study, five of which came from mandibular dental series and three of which were isolated teeth (Table 1). Because M3 generally show more inter-individual variability in the timing of enamel formation, M2 were used (Blaise and Balasse 
Fig. 2 Synthesis data provided by the study of the faunal remains of El Mirador from the occupations of the 6th and 5th millennia BC (Martín 2015; Martín et al. 2016). These data include the distribution of the NIM by age; where possible, it is noted whether it is a sheep $(\mathrm{O})$ or a goat $(\mathrm{C})$. The determination of the age of foetal and neonatal individuals was done following the criteria of Martín and García-González (2015). Postnatal age classification was performed using Payne's methodology (1973)

\section{General zooarchaeological data}

\begin{tabular}{|c|c|c|c|c|c|c|c|c|c|c|c|c|c|c|}
\hline & MIR2 & MIR23 & MIR2 & MIR21 & MIR20 & MIR1S & MIR18 & MIR17 & MIR16 & MIR15 & MIR14 & 4 MIR13 & MIR12 & MIR11 \\
\hline NR & 80 & 130 & 110 & 630 & 425 & 740 & 762 & 91 & 1386 & 303 & 269 & 352 & 465 & 1364 \\
\hline NISP & 34 & 45 & 46 & 277 & 140 & 229 & 276 & 35 & 434 & 96 & 138 & 135 & 130 & 179 \\
\hline MNI & 5 & 5 & 4 & 12 & 11 & 16 & 22 & 5 & 19 & 8 & 10 & 12 & 12 & 18 \\
\hline
\end{tabular}

Domestic caprine representation
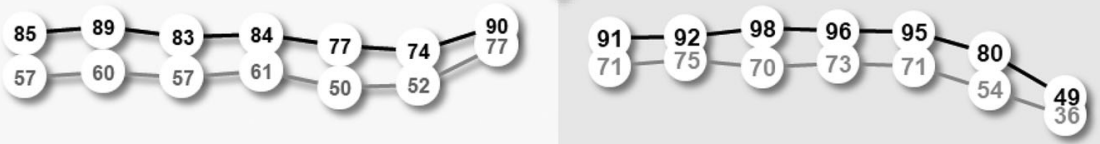

MIR24 MIR23 MIR22 MIR21 MIR20 MIR19 MIR18

MIR17 MIR16 MIR15 MIR14 MIR13 MIR12 MIR11 $-\% \mathrm{NISP}-\% \mathrm{MNI}$

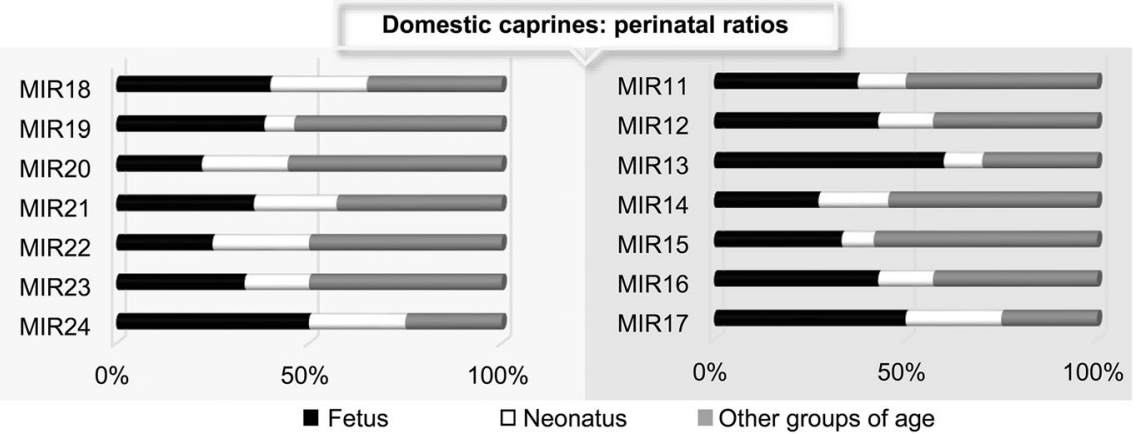

Distribution of MNI by age at death

\begin{tabular}{|c|c|c|c|c|c|c|c|c|c|}
\hline Period & \multicolumn{3}{|c|}{ Gestation } & \multicolumn{5}{|c|}{ Postnatal } & \multirow{3}{*}{ Total } \\
\hline Phases & I & II & III & $\overline{\mathrm{A}}$ & $\bar{B}$ & $\mathrm{C}$ & $\overline{\mathrm{D}}$ & E and others & \\
\hline Levels & End 3th & 4th & 5 th & $0-1$ & $1-6$ & $6-12$ & $12-24$ & $>24$ & \\
\hline MIR24 & & $1 \mathrm{O} / \mathrm{C}$ & $1 \mathrm{O} / \mathrm{C}$ & $1 \mathrm{O} / \mathrm{C}$ & & & $1 \mathrm{C}$ & & 3 \\
\hline MIR23 & & & $2 \mathrm{O} / \mathrm{C}$ & 10 & & & & $10+1 c$ & 5 \\
\hline MIR22 & & & $1 \mathrm{O} / \mathrm{C}$ & $1 \mathrm{O} / \mathrm{C}$ & & & & $10+1 C$ & 4 \\
\hline MIR21 & $1 \mathrm{O} / \mathrm{C}$ & $1 \mathrm{O} / \mathrm{C}$ & $3 \mathrm{O} / \mathrm{C}$ & $3 \mathrm{O} / \mathrm{C}$ & & 20 & & 30 & 13 \\
\hline MIR20 & & $1 \mathrm{O} / \mathrm{C}$ & $1 \mathrm{O} / \mathrm{C}$ & $2 \mathrm{O} / \mathrm{C}$ & & & 10 & $1 \mathrm{O} / \mathrm{C}+1 \mathrm{O}$ & 7 \\
\hline MIR19 & $1 \mathrm{O} / \mathrm{C}$ & $2 \mathrm{O} / \mathrm{C}$ & $2 \mathrm{O} / \mathrm{C}$ & $1 \mathrm{O} / \mathrm{C}$ & $1 O / C+1 C$ & 10 & $1 O / C+1 O$ & $2 \mathrm{C}$ & 13 \\
\hline MIR18 & $1 \mathrm{O} / \mathrm{C}$ & $2 \mathrm{O} / \mathrm{C}$ & $5 \mathrm{O} / \mathrm{C}$ & $5 \mathrm{O} / \mathrm{C}$ & $10+1 c$ & $2 \mathrm{O} / \mathrm{C}$ & $10+2 C$ & & 20 \\
\hline
\end{tabular}

\begin{tabular}{|c|c|c|c|c|c|c|c|c|c|}
\hline Period & \multicolumn{3}{|c|}{ Gestation } & \multicolumn{5}{|c|}{ Postnatal } & \multirow{3}{*}{ Tota } \\
\hline Phases & I & II & III & $\bar{A}$ & $\bar{B}$ & $\mathrm{C}$ & $\bar{D}$ & E and others & \\
\hline Levels & End 3th & 4th & 5 th & $0-1$ & $1-6$ & $6-12$ & $12-24$ & $>24$ & \\
\hline MIR17 & $1 \mathrm{O} / \mathrm{C}$ & $1 \mathrm{O} / \mathrm{C}$ & $1 \mathrm{O} / \mathrm{C}$ & & & & & $1 \mathrm{O} / \mathrm{C}$ & 4 \\
\hline MIR16 & $1 \mathrm{O} / \mathrm{C}$ & $3 \mathrm{O} / \mathrm{C}$ & $5 \mathrm{O} / \mathrm{C}$ & $2 \mathrm{O} / \mathrm{C}$ & $2 \mathrm{C}$ & & $\begin{array}{c}1 \mathrm{O} / \mathrm{C}+ \\
1 \mathrm{C}\end{array}$ & $2 \mathrm{O}+1 \mathrm{C}$ & 18 \\
\hline MIR15 & $1 \mathrm{O} / \mathrm{C}$ & $1 \mathrm{O} / \mathrm{C}$ & $2 \mathrm{O} / \mathrm{C}$ & $1 \mathrm{O} / \mathrm{C}$ & & & & $2 \mathrm{O} / \mathrm{C}$ & 7 \\
\hline MIR14 & $1 \mathrm{O} / \mathrm{C}$ & $1 \mathrm{O} / \mathrm{C}$ & $1 \mathrm{O} / \mathrm{C}$ & $2 \mathrm{O} / \mathrm{C}$ & $1 \mathrm{O} / \mathrm{C}$ & 20 & $1 \mathrm{C}$ & $1 \mathrm{O} / \mathrm{C}+1 \mathrm{O}$ & 11 \\
\hline MIR13 & $1 \mathrm{O} / \mathrm{C}$ & $3 \mathrm{O} / \mathrm{C}$ & $2 \mathrm{O} / \mathrm{C}$ & $1 \mathrm{O} / \mathrm{C}$ & $1 \mathrm{C}$ & & & 20 & 10 \\
\hline MIR12 & & $1 \mathrm{O} / \mathrm{C}$ & $2 \mathrm{O} / \mathrm{C}$ & $1 \mathrm{O} / \mathrm{C}$ & $1 \mathrm{C}$ & 10 & & $1 \mathrm{O} / \mathrm{C}$ & 7 \\
\hline MIR11 & & $1 \mathrm{O} / \mathrm{C}$ & $2 \mathrm{O} / \mathrm{C}$ & $1 \mathrm{O} / \mathrm{C}$ & $1 \mathrm{O} / \mathrm{C}+1 \mathrm{O}$ & 10 & & $1 \mathrm{C}$ & 8 \\
\hline
\end{tabular}

2011; Tornero et al. 2013; Balasse et al. 2020). M2 are mainly formed during the first year of life, from 2-3 months to 12 months of age (Weinreb and Sharav 1964; Milhaud and Nezit 1991).

Sampled teeth came from eight different individuals that came from five archaeological levels dating to the second half of 6th and 5th millennium cal BCE (Table 1).

The identification of the remains as Ovis aries was carried out using morphological criteria established by various authors (Payne 1985; Helmer 2000; Halstead et al. 2002; Zeder and Pilaar 2010; Gillis et al. 2011). Individuals were identified by examining tooth laterality and dental age. Dental age was determined using criteria of eruption and tooth wear (Ducos 1968; Payne 1973; Deniz and Payne 1982; Payne 1985; Gourichon 2004; Jones 2006; Greenfield and Arnold 2008) and root development (Hillson 2005) (Table 1).

Tooth enamel was sampled horizontally and in sequential bands. Firstly, tooth surfaces were cleaned with a tungsten 
Table 1 Description of the specimens (M2) analysed: laboratory acronym, level of origin of the sample, description of the dental series, dental wear stage of the specimen after Payne criteria (1973), age estimation (years) according Payne's dental stage.

\begin{tabular}{lllll}
\hline Individuals & Level & Dental series description & $\mathrm{M}_{2}$ wear stage & Age estimation \\
\hline MIR Ovis 01 & MIR16 & $\mathrm{P}_{4}-\mathrm{M}_{2}$ & $\mathrm{DE}$ & $2-3$ \\
MIR Ovis 02 & MIR16 & $\mathrm{dP}_{4}-\mathrm{M}_{2}$ & $\mathrm{D}$ & 2 \\
MIR Ovis 03 & MIR16 & $\mathrm{M}_{2}$ & $\mathrm{DE}$ & $1-2$ \\
MIR Ovis 05 & MIR15 & $\mathrm{M}_{2}$ & $\mathrm{DE}$ & $1-2$ \\
MIR Ovis 06 & MIR14 & $\mathrm{P}_{4}-\mathrm{M}_{3}$ & EFG & $3-4$ \\
MIR Ovis 07 & MIR15 & $\mathrm{M}_{2}$ & $\mathrm{DE}$ & $1-2$ \\
MIR Ovis 08 & MIR24 & $\mathrm{M}_{1}-\mathrm{M}_{3}$ & $\mathrm{D}$ & $1-2$ \\
MIR Ovis 09 & MIR19 & $\mathrm{P}_{4}-\mathrm{M}_{2}$ & EFG & $3-4$ \\
\hline
\end{tabular}

abrasive drill bit. Then, sequential samples of enamel were removed from the anterior lobes and the buccal sides of the teeth by drilling with a diamond bit. The distance of each drilled sample from the enamel-root junction (ERJ) was recorded (in mm). In total, 124 tooth enamel bands were sampled for oxygen and carbon isotopic analyses.

Powdered enamel samples were chemically treated at the Biomolecular Laboratory of the Institut Català de Paleoecologia Humana i Evolució Social (IPHES).

Samples weighed from 3.3 to $8.8 \mathrm{mg}$. Chemical treatment of samples was based on protocols originally proposed by Koch et al. (1997) and later modified in Tornero et al. (2013). Samples were treated for $4 \mathrm{~h}$ in $0.1 \mathrm{M}$ acetic acid $\left[\mathrm{CH}_{3} \mathrm{COOH}\right](0.1 \mathrm{ml}$ solution $/ 0.1 \mathrm{mg}$ of sample), neutralized with distilled water and freeze-dried. As a result, the samples lost an average of $39 \pm 8.9 \%$ of their weight.

Treated enamel powder samples were analysed on a GasBench II coupled with an isotope ratio mass spectrometer (Thermo Finnigan Delta V) at the Stable Light Isotope Laboratory of the University of Cape Town, in South Africa. They were reacted in a vacuum with $100 \%$ phosphoric acid $\left[\mathrm{H}_{3} \mathrm{PO}_{4}\right]$ at $70^{\circ} \mathrm{C}$ in individual vessels and purified in an automated cryogenic distillation system. $\delta^{13} \mathrm{C}$ and $\delta^{18} \mathrm{O}$ values are expressed in the Vienna-Pee Dee Belemnite (V-PDB) standard. Accuracy and precision of the measurements were checked using an internal laboratory calcium carbonate standard (Marbre CM normalised to NBS 18 and NBS19 international standards). Over the period of analysis, a total of 20 Marbre CM samples were measured (expected values $+0.34 \%$ of $\delta^{13} \mathrm{C}$ and $-8.95 \%$ o for $\delta^{18} \mathrm{O}$ ) (SI 1 ). Mean analytical precision of Marbre $\mathrm{CM}$ within each series was $+0.13 \pm$ $0.071 \%$ ofor $\delta^{13} \mathrm{C}$ and $+0.06 \pm 0.043 \%$ or for $\delta^{18} \mathrm{O}$ values.

Finally, in order to eliminate inter-individual variability in tooth size, sequences of $\delta^{18} \mathrm{O}$ values were modelled following the cosine function proposed by Balasse et al. (2012a). The model includes the following parameters: $\mathrm{X}$ (period of the cycle in $\mathrm{mm}$ that corresponds to the length of the crown formed over a year); A (max-min)/2; amplitude of stable isotope signal measured in enamel in \%o); $\mathrm{M}$ (mean in \%o); and $\mathrm{x}_{0}$ (delay, i.e. position in tooth crown where $\delta^{18} \mathrm{O}$ is the highest).
The model's fit was estimated using Pearson's correlation coefficient (Siegel and Castellan 1988).

Normalised $\mathrm{X}_{0} / \mathrm{X}$ values from El Mirador cave specimens were compared with data from modern sheep dataset references with known lambing seasons to fit the season of birth on the archaeological specimens. These reference data included individuals born in late winter/early spring (Blaise and Balasse 2011; Balasse et al. 2012a; Balasse et al. 2017) and autumn (Blaise and Balasse 2011; Tornero et al. 2018).

\section{Results}

Results from $\delta^{13} \mathrm{C}$ and $\delta^{18} \mathrm{O}$ analyses are summarised in Table 2 and fully presented in the Supplementary Information (SI2).

The mean $\delta^{18} \mathrm{O}$ value of all samples was $-3.6 \pm 1.6 \%$ and values ranged from $0.1 \%$ o to $-6.6 \%$. Mean values for each specimen ranged from -2.1 to $4.7 \%$, maximum values ranged between 0.1 and $-2.8 \%$, and minimum values ranged between -4.1 and $6.6 \%$.

The mean $\delta^{13} \mathrm{C}$ values of all samples was $-12.5 \pm 0.62 \%$ o and values ranged from -10.91 to $-14.17 \%$. Mean values for each specimen ranged from -11.8 to $-13.7 \%$, maximum values ranged from -10.9 to $-13.2 \%$, and minimum values varied between -12.3 and $-14.2 \%$.

Whole sequences of $\delta^{13} \mathrm{C}$ and $\delta^{18} \mathrm{O}$ values are presented in Fig. 3. Both $\delta^{13} \mathrm{C}$ and $\delta^{18} \mathrm{O}$ sequences showed high intra-tooth variation that followed a sinusoidal pattern. These distributions demonstrate maximum and minimum peak events in the sequences. Maximum $\delta^{18} \mathrm{O}$ peak events were related to the warmest seasonal episodes and minimum peak events to the coldest seasonal episodes. The duration of the sequences was variable for each sampled specimen because of differences in crown heights due to wear stage and diminution of the tooth crown. Some specimens were about 1 year old (i.e. MIR_Ovis_07 and 08), others about 6 to 9 months (MIR_Ovis_01, 02, 03, 05, and 09), and MIR Ovis 06 was younger than 6 months. Based on histological studies, the presence of longer sequences in specimens MIR Ovis 07 
Table 2 Summarised $\delta^{18} \mathrm{O}_{\mathrm{V}-}$ PDB $\%$ and $\delta^{13} \mathrm{C}_{\mathrm{V}-\mathrm{PDB}} \%$ o data for each analysed individual

\begin{tabular}{|c|c|c|c|c|c|c|c|c|c|}
\hline \multirow[t]{2}{*}{ Individuals } & \multirow[t]{2}{*}{$\mathrm{N}$} & \multicolumn{4}{|c|}{$\delta^{18} \mathrm{O}_{\mathrm{V}-\mathrm{PDB}} \% 0$} & \multicolumn{4}{|c|}{$\delta^{13} \mathrm{C}_{\mathrm{V}-\mathrm{PDB}} \% 0$} \\
\hline & & Mean & Range & Max. & Min. & Mean & Range & Max. & Min. \\
\hline MIR Ovis 01 & 16 & -3.3 & 1.6 & -1.7 & -5.0 & -12.1 & 0.5 & -11.8 & -12.3 \\
\hline MIR Ovis 02 & 17 & -2.1 & 4 & 0.1 & -4.1 & -11.8 & 1.4 & -10.9 & -12.3 \\
\hline MIR Ovis 03 & 17 & -4.4 & 3.9 & -2.4 & -6.3 & -12.7 & 1.3 & -11.9 & -13.2 \\
\hline MIR Ovis 05 & 17 & -4.7 & 4.7 & -1.9 & -6.6 & -13.0 & 1 & -12.6 & -13.6 \\
\hline MIR Ovis 06 & 12 & -2.8 & 3.8 & -1.6 & -5.4 & -13.7 & 1 & -13.2 & -14.2 \\
\hline MIR Ovis 07 & 16 & -4.2 & 2.9 & -2.8 & -5.7 & -11.9 & 0.8 & -11.5 & -12.3 \\
\hline MIR Ovis 08 & 18 & -3.1 & 4.7 & -0.9 & -5.6 & -12.4 & 1.6 & -11.7 & -13.3 \\
\hline MIR Ovis 09 & 11 & -3.8 & 4.4 & -1.3 & -5.7 & -12.8 & 0.6 & -12.4 & -13.0 \\
\hline
\end{tabular}

and 08 is expected given the length of the period of enamel formation in sheep M2 teeth (Weinreb and Sharav 1964; Hillson 2005; Green et al. 2017).

Inter-individual variability in the distance from the ERJ to the maximum $\delta^{18} \mathrm{O}$ peak within the crown of the M2 may be a consequence of differences in birth seasonality. Following this observation, sampled specimens can be grouped into two different categories: (a) those specimens whose maximum $\delta^{18} \mathrm{O}$ value peaks between 3.41 and $9 \mathrm{~mm}$ from the ERJ; and (b) a two specimens (MIR_Ovis_06 and MIR_Ovis_07) whose maximum sequence peaks are between 11 and $22 \mathrm{~mm}$ from the ERJ.
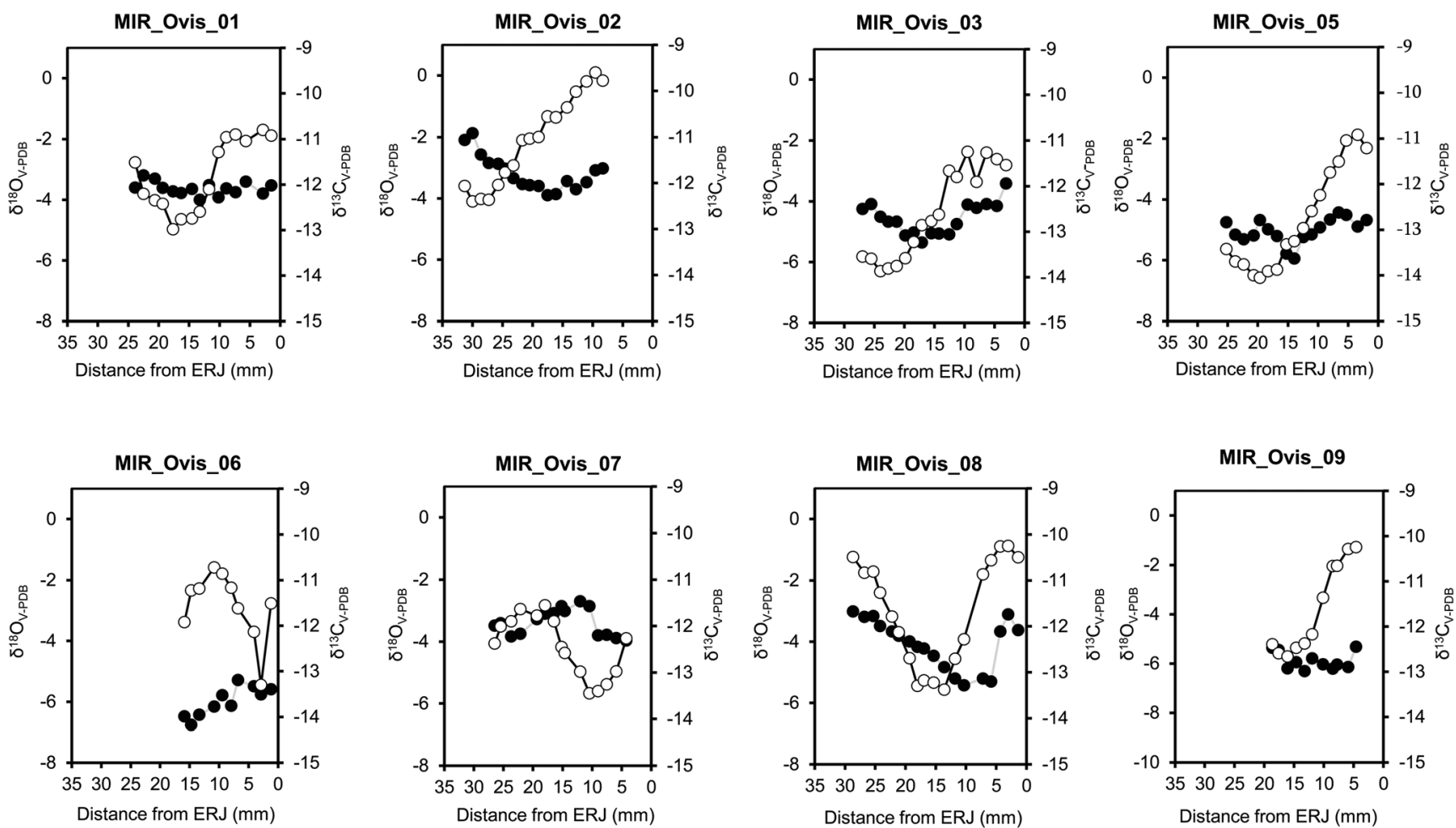

To estimate differences in birth seasons between sampled specimens, these oxygen sequences were modelled following the cosine function in Balasse et al. (2012a). Results from the calculation of the best fit are presented in Table 3 . The specimen MIR_Ovis_06 was not selected for this process due to its short isotopic sequence. In all specimens, Pearson's correlation coefficients were higher than 0.97 , indicating that the models were accurate (Table 3 ). Normalised $\mathrm{x}_{0} / \mathrm{X}$ values from El Mirador cave ranged from 0.13 to 0.93 (Fig. 4). Excluding value 0.93 of MIR_Ovis_07, the rest of the individuals showed values similar to those observed in modern sheep born between late winter and mid-spring. Indeed, within this group,

Fig. 3 Stable carbon $\left(\delta^{13} \mathrm{C}\right)$ (black symbols) and oxygen $\left(\delta^{18} \mathrm{O}\right)$ (white symbols) isotope values measured in El Mirador sheep M2 
Table 3 Results from the calculation of the best fit (by method of least squares) for combined variation of X (period), A (amplitude), $\mathrm{x} 0$ (delay), and M (mean). The Pearson's correlation coefficient (R) was also calculated

\begin{tabular}{lllllll}
\hline Specimens & $X(\mathrm{~mm})$ & $A(\%)$ & $x_{0}(\mathrm{~mm})$ & $M(\% \circ)$ & $R$ & $x_{0} / X$ \\
\hline MIR Ovis 01 & 24.61 & 1.6 & 4.74 & -3.1 & 0.972 & 0.19 \\
MIR Ovis 02 & 33.01 & 1.8 & 11.54 & -2.0 & 0.973 & 0.35 \\
MIR Ovis 03 & 33.65 & 1.8 & 6.68 & -4.4 & 0.981 & 0.20 \\
MIR Ovis 05 & 31.40 & 2.2 & 4.01 & -4.4 & 0.991 & 0.13 \\
MIR Ovis 07 & 22.36 & 1.4 & 20.75 & -4.1 & 0.976 & 0.93 \\
MIR Ovis 08 & 25.29 & 2.2 & 3.21 & -3.3 & 0.991 & 0.13 \\
MIR Ovis 09 & 22.15 & 2.3 & 4.88 & -3.5 & 0.996 & 0.22 \\
\hline
\end{tabular}

all sheep were born in late winter and early spring and the duration of the lambing period can be estimated to about 2.64 months $(0.22$ year) ( $\max -\min \mathrm{x} 0 / \mathrm{X}$ values: 0.35 in MIR_Ovis_02, 0.13 in MIR_Ovis_08 and MIR_Ovis_05). Conversely, MIR_Ovis_07 is similar to modern sheep specimens born in mid-autumn. The unmodelled MIR_Ovis_06 sheep could also represent a birth occurring in autumn (Fig. 4).

\section{Discussion}

In this study we carried out an isotopic study $\left(\delta^{18} \mathrm{O}\right.$ and $\left.\delta^{13} \mathrm{C}\right)$ of several individuals of sheep coming from the earliest occupations of El Mirador, with the aim of deepening our understanding of the beginning of livestock practices at this site and in inland Iberia. We focused on the observation of the reproductive seasonality of sheep, their management and exploitation.

\section{Seasonality of births and lambing period length}

Isotopic data from El Mirador cave confirm the general trend for Neolithic sheep with a predominance of births in late winter and early spring (Tornero et al. 2016a, 2016b; Balasse et al. 2017, 2020).

Caprine reproduction is seasonal, with periods of ovulation and periods of anoestrus. This reproductive behaviour is regulated by photoperiodic control in both wild and domestic species. In temperate latitudes, the birth period occurs at the end of winter and during the spring (e.g. Hafez 1952; Santiago-Moreno et al. 2000; Cassinello 2017). This even is the case in some current Iberian domestic herds in which the shepherd does not intervene in the reproductive cycle (Violant i Simorra 2001; Miralles and Tutusaus 2005).

However, the process of domestication itself caused changes in the reproductive cycles of these animals such as those linked to management by the shepherd, for example via control of diet or in males' sexual access to females (Hafez 1952; Dwyer 2008). One of the consequences of this process was an increase in the variability of the length of the birthing period, which is directly linked to an extension of the ovulation period of the ewes. For example, populations of modern mouflon, located in the Near East or the Iberian Peninsula, show a lambing period of 1-2 months (Valdez 2008; Cassinello 2017) but populations bred in captivity in the Iberian Peninsula present more extended lambing periods (SantiagoMoreno et al. 2000). The Early Neolithic domestic sheep of the Middle East (8th millennium) (Tornero et al. 2016a) and Europe (6th millennium) had a longer lambing period than wild sheep (Balasse et al. 2017, 2020).

The winter/spring birthing season of El Mirador cave sheep extended over 2.64 months (Fig. 4). This is similar to the lambing period observed at Tell Halula (PPNB, Syria; early evidence of domestic sheep) (Tornero et al. 2016a), and is

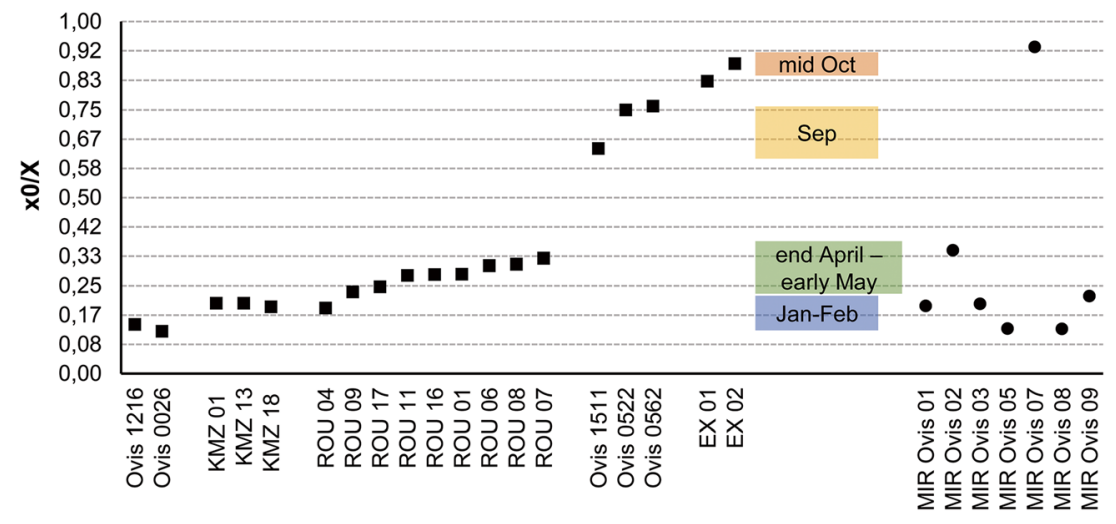

Fig. 4 Results from normalisation of the position in the M2 crown for the highest $\delta^{18} \mathrm{O}$ value $\left(\mathrm{x}_{0}\right)$, using the period $(\mathrm{X})$ of the cycle. Comparison of El Mirador datasets with modern reference sets. Raw data of domestic ewes from the primitive 'southern pre-Alps' breed, raised on the Carmejane farm (France) (Ovis 1216, Ovis 0026, Ovis 1511, Ovis 0522, Ovis 0562) after Blaise and Balasse (2011); raw data of sheep form

a OuessantxLandes de Bretagne cross, raised on the island of Kemened (KMZ) after Balasse et al. (2017); raw data of sheep from a Shetland cross, from the island of Rousay in Orkney (ROU) after Balasse et al. 2012a, 2012b); raw data of Xisqueta sheep raised on a working farm in the Ebro Valley (Spain) (XT) after Tornero et al. (2018). 
slightly shorter than the 3-4 month duration of the Neolithic sites of the early 6th millennium in the Balkans and Central Europe (Balasse et al. 2017, 2020), characterised by a mixed farming economy that was fully consolidated (e.g. Nikolov 2007).

The case of El Mirador cave could be one more evidence of the relationship between domestication and the extension of the period of sexual activity of the sheep, suggested by other authors (Hafez 1952; Balasse et al. 2017).

In El Mirador cave, there is also a particularity, with the presence of the individual MIR_Ovis_02 that was born in late April or early May. This individual is an outlier in the group of El Mirador winter/spring births since he was born in a late date, more similar to the one presented by the sheep of higher latitudes, such as the Orkney sheep (Hafez 1952; Balasse et al. 2017). The other three winter/spring individuals were born in period more reduced to 1.08 months $(0.09$ year) ( $\max \min \mathrm{x} 0 /$ $\mathrm{X}$ values; 0.22 in MIR_Ovis_09, 0.13 in MIR_Ovis_08).

The decisions of the herder could have been of great importance both for the achievement of these four births. The birth of the individual MIR_Ovis_02 means a breeding season in a time of harsh weather conditions in late autumn so it would be necessary a good nutritional state of the ewe. The concentration of the other three births in 1 month could have been of benefit to the herder.

To concentrate births into a relatively short timeframe would have helped herder have greater control over and provide better care to newborns and ewes who had just given birth at a complex time in the annual livestock cycle (Represa 1998). It would also help to make sheep breeding compatible with other domesticates' breeding cycles and with other activities there. Based on available ethnographic and zootechnical data, control over lambing cycles may have been exerted in various ways without chemical intervention (Hammond 1940; Hjort and Dahl 1991; Seguí 1999). Some of the most common traditional techniques are the separation of males and females into different herds or the covering of male genitals, which causes males to become sexually aroused by contact with the females when the cover is removed ('male effect') (Owen et al. 1994; Gómez-Brunet et al. 2012). The practice of separating the herds by sex at El Mirador has already been proposed (Martín 2015) on the basis of a series of criteria shared with other sheepfold caves (Beeching et al. 2000; Helmer et al. 2005a, 2005b; Miracle and Forenbaher 2005; Miracle 2006; Bréhard et al. 2010): (1) similar specialised use of the caves as folds, (2) the clear predominance of domestic caprines over other domestic species, and (3) the abundance of perinatal individuals amongst domestic caprines.

Archaeological and isotopic evidence indicates a fast adaptation of domestic sheep in the inland of the Iberian Peninsula during the Early Neolithic (Saña et al. 2020; TejedorRodríguez et al. 2021). This is the reason why, although the influence of natural factors (such as climatic conditions) cannot be ruled out to explain the seasonality of the births at El Mirador and a larger sample is needed, it is reasonable to hypothesise the intervention should also be assessed.

The intervention of the shepherd in the reproduction of the flock could also be related to the presence of the two autumn births at El Mirador cave. The two identified specimens came from archaeological levels MIR 14 (MIR_Ovis_06) and MIR 15 (MIR_Ovis_07), dated to the second half of the 5th millennium cal BCE. As mentioned above, although the reproductive seasonality of sheep is regulated by photoperiodic control, other factors can influence it as well (Rose and Bryant 2003; Gómez-Brunet et al. 2012). In fact, under the management of the herder, current sheep breeds in the Iberian Peninsula (e.g. Manchega, Rasa Aragonesa, or Merino breeds) have a long breeding season (from summer to winter) with seasonal anoestrus that lasts about 3-4 months (SantiagoMoreno et al. 2000; Gómez-Brunet et al. 2012).

For this to occur, the adaptation of the sheep to their environment and the intervention of the shepherd's care are very important. This intervention can be more or less intense and focus on different areas of herd management, which are usually interrelated, e.g. feeding supplements, sexual stimulation, or weaning decisions (Rose and Bryant 2003).

Earliest isotopic evidence of archaeological sheep born in autumn has been documented in Cyprus, in occupations of Cypro-Late PPNB (7600-6900 cal BCE) of ParekklishiaShillourokambos and Kritou Marottou-Ais Yiorkis. The authors note that this is the birth period currently recorded in ethnozooarchaeological studies, because the arid Cypriot climate links to a period of greater pasture availability (Hadjíkoumis et al. 2019). However, the cases of El Mirador present some differences. In the El Mirador region, pastures shrink drastically in mid-autumn, although the availability of other foods, such as acorns, increases. In addition, autumnal weather is harsher, with an increase in humidity and a decrease in temperatures (Fig. 5). Moreover Parekklishia-Shillourokambos and Kritou MarottouAis Yiorkis are located at a lower latitude $\left(34^{\circ} \mathrm{N}\right)$ than $\mathrm{El}$ Mirador $\left(42^{\circ} \mathrm{N}\right)$; this shifted periodicity may have affected sheep reproduction there (Hafez 1952).

Recent publications evidence autumn sheep births from the Early Neolithic in southern France (6th millennium cal BCE) (Tornero et al. 2020) and the southern slopes of the Central Pyrenees, in the Iberian Peninsula (6th-4th millennium cal BCE) (Tejedor-Rodríguez et al. 2021) sites. In both cases, the success of these births is attributed to human intervention and shepherding activities. Els Trocs cave data (TejedorRodríguez et al. 2021) are especially interesting because of its location in the inland of the Iberian Peninsula. These pieces of evidence, together with that of El Mirador, would confirm the process of adaptation of the sheep to the climatic and environmental conditions of the Iberian interior and the rapid consolidation of husbandry practices in this area. 

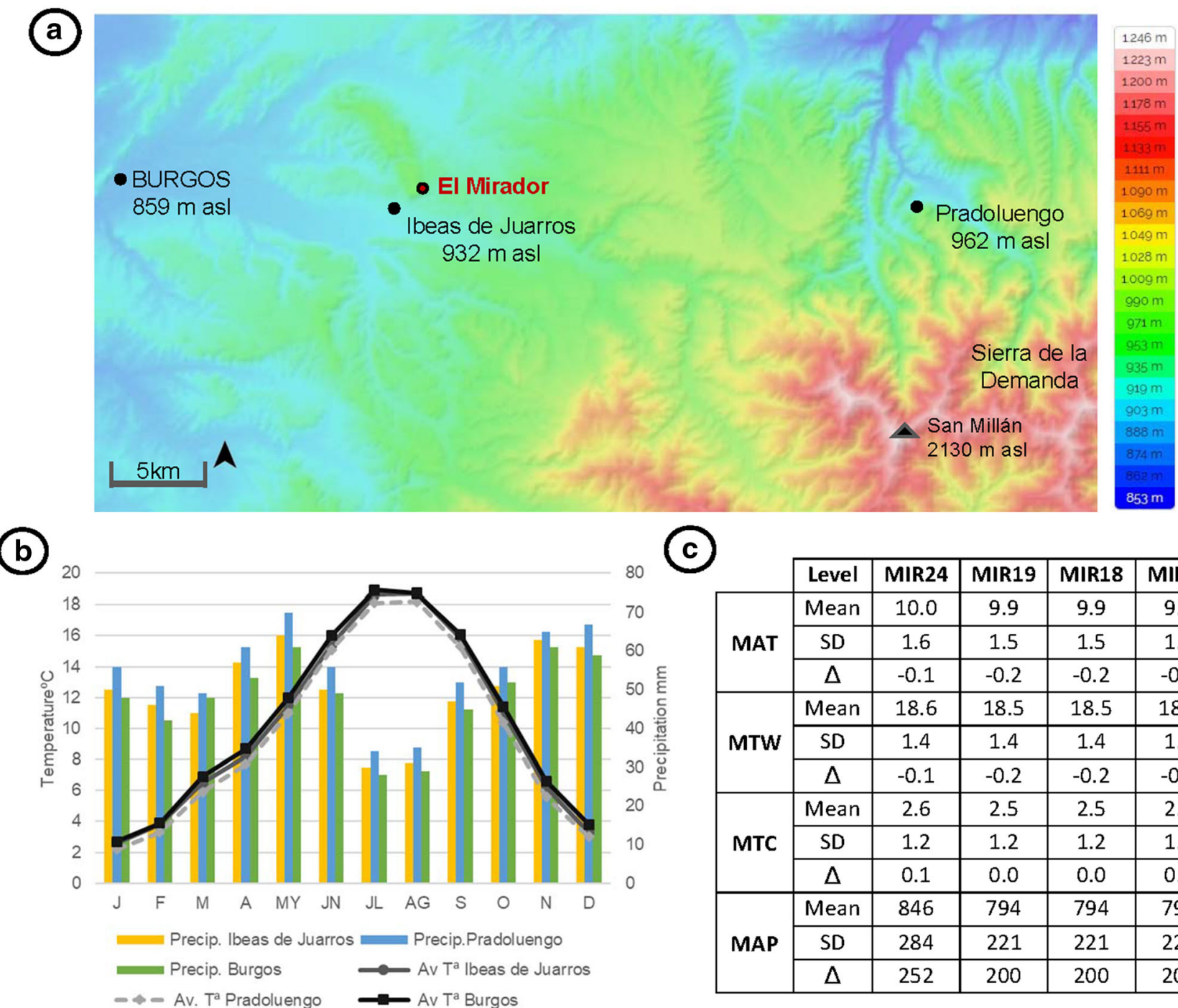

b

Fig. 5 Climatic data from the El Mirador cave region. a. Altitude map of the areas surrounding El Mirador cave with the climatic reference points used for the climate graph. b. Climate graph with current data (19822012), average temperatures/month and average rainfall/month (source: climate-data.org). c. Temperatures and precipitation from the 6th millennium (MIR24, MIR19, MIR18) and 5th millennium (MIR17) occupations of El Mirador cave, obtained from the MER (Mutual

\section{The dietary and mobile management of sheep herds at El Mirador cave}

The potential schedule and modification of the reproductive sheep cycle at El Mirador would imply, at least and amongst other factors, that the nutritional state of the flocks was good, especially the females (i.e. Hafez 1952; Forcada et al. 1992; León et al. 2005). In this sense, the shepherds of the Iberian Peninsula have traditionally used different techniques to provide food to the herds throughout the year, e.g. through the provisioning of foraging or the practice of seasonal movements, amongst others (e.g. Cambero 1997; Violant i Simorra 2001; Miralles and Tutusaus 2005).

\begin{tabular}{|c|c|c|c|c|c|}
\hline & Level & MIR24 & MIR19 & \begin{tabular}{|l|} 
MIR18 \\
\end{tabular} & MIR17 \\
\hline \multirow{3}{*}{ MAT } & Mean & 10.0 & 9.9 & 9.9 & 9.9 \\
\hline & SD & 1.6 & 1.5 & 1.5 & 1.5 \\
\hline & $\Delta$ & -0.1 & -0.2 & -0.2 & -0.2 \\
\hline \multirow{3}{*}{ MTW } & Mean & 18.6 & 18.5 & 18.5 & 18.5 \\
\hline & SD & 1.4 & 1.4 & 1.4 & 1.4 \\
\hline & $\Delta$ & -0.1 & -0.2 & -0.2 & -0.2 \\
\hline \multirow{3}{*}{ MTC } & Mean & 2.6 & 2.5 & 2.5 & 2.5 \\
\hline & SD & 1.2 & 1.2 & 1.2 & 1.2 \\
\hline & $\Delta$ & 0.1 & 0.0 & 0.0 & 0.0 \\
\hline \multirow{3}{*}{ MAP } & Mean & 846 & 794 & 794 & 794 \\
\hline & SD & 284 & 221 & 221 & 221 \\
\hline & $\Delta$ & 252 & 200 & 200 & 200 \\
\hline
\end{tabular}

Ecogeographic Range) analysis of micromammal remains (BañulsCardona and López-García 2016). MAT (mean annual temperature); MTW (mean temperature of the warmest month); MTC (mean temperature of the coldest month); MAP (mean annual precipitation); SD (standard deviation); $\Delta$ (difference in relation to the current means at meteorological stations) (Table modified from Bañuls-Cardona and LópezGarcía (2016)

At El Mirador, sheep samples show a small range of $\delta^{13} \mathrm{C}$ values ( $\max -\min \delta^{13} \mathrm{C}$ values) within sequential series. This could be an indicator that these animals ate in a fairly homogeneous environment throughout the annual cycle. Furthermore, the oscillation of the $\delta^{13} \mathrm{C}$ sequences seems to follow the same pattern as that recorded in $\delta^{18} \mathrm{O}$ sequences in many specimens, hence the same climatic variation.

These data are in accordance with the climatic and paleoclimatic information of the region. The areas surrounding the Sierra de Atapuerca have a temperate oceanic climate ' $\mathrm{Cfb}$,' (following the Köppen climate classification). Unlike the Mediterranean 'Csa' climate and Ebro Valley 'BSk' climate, ' $\mathrm{Cfb}$ ' climate regions do not have dry seasons, rather they 
have temperate summers with rainfall evenly distributed throughout the year, though with a slight decrease during the summer (AEMET 2011). Currently, the environment of El Mirador would be similar to that documented through the archaeological record (Rodríguez et al. 2016), although with a greater extension of open areas, due to urbanization and crop fields. The studies on micromammals recovered from the occupations from the 6th and 5th millennia cal BCE of El Mirador indicate that climatic conditions were also similar to those of the present, although with slightly higher rainfall levels (Bañuls-Cardona and López-García 2016) (Fig. 5). These climatic characteristics and the vegetal mosaic that surrounded the cave of El Mirador could have provided resources for feeding the flock throughout the year without the sheep having to move large distances in search of pastures. This use of the nearest territory for feeding has also been documented in the Early Neolithic sheep at La Draga (northeastern Iberian Peninsula), also using combined $\delta^{13} \mathrm{C}$ and $\delta^{18} \mathrm{O}$ (Navarrete et al. 2019).

Another noteworthy aspect of El Mirador is the low $\delta^{13} \mathrm{C}$ values (lowered to $-12.8 \%$ ) observed in some individuals (MIR_Ovis_03, 05, and 08) but, especially in MIR_Ovis_06, coinciding, again, with a time of falling temperatures marked by low $\delta^{18} \mathrm{O}$ values (Fig. 3). In temperate latitudes, some studies have shown that the $\delta^{13} \mathrm{C}$ values in tree species are more negative, especially in thicker forests, due to the so-called 'canopy effect' (van der Merwe and Medina 1991; Drucker et al. 2008). Similar low $\delta^{13} \mathrm{C}$ values to those of El Mirador cave have also been documented in the Early Neolithic sheep of southern France sites of Täi and Gazel (Tornero et al. 2020). These could reflect a contribution of leaf fodder in sheep diet.

At El Mirador, these data could be evidence of the development of two techniques for feeding herds, which are not mutually exclusive: (1) the consumption by sheep of tree resources found in areas surrounding the cave, and (2) dietary supplementation with leaf fodder brought into the fold by the shepherd. At El Mirador, archaeobotanical studies have already suggested the possibility of using fodder to supplement herd feeding in the winter (Allué and Euba 2008; Euba et al. 2016; Rodríguez et al. 2016). The use of leaf fodder to reinforce herd feeding has also been supported by anthracological studies carried out in several sheepfold caves in Mediterranean contexts (Badal 1999; Thiébault 2005; Delhon et al. 2008; Allué et al. 2009). At El Mirador, a high percentage of charcoal from deciduous oak young branches has been documented. They presented tree rings with a rapid growth rate which could indicate that the trees were regularly shredded that could be related to their collection as fodder for livestock (Allué and Euba 2008; Euba et al. 2016). This would complement the use of evergreen oak leaves and herbaceous forage and seeds, that appear in fields and pastures (e.g. Bromus spp., Lolium spp., Mendicago spp., Melilotus spp.,
Trifolium repens and Trifolium spp.), which have also been identified at these levels in El Mirador (Rodríguez et al. 2016).

In addition, although the unmonitored consumption of woody plants is related to goats, who are eminent browsers, the use of woody forage for feeding sheep is also documented ethnographically (Solecki 1979; Halstead 1998; Seguí 1999; Zapata et al. 2003) and by ecological and agrarian studies (Ramos 2009). This option would also leave open the possibility that the low $\delta^{13} \mathrm{C}$ values could be related to the free consumption of woody plants by the sheep of El Mirador.

Regarding shepherding movements, we also found three individuals (MIR_Ovis_02, 06 and 07) with an almost inverse relationship between their carbon and oxygen curves. The inverse relationship between $\delta^{13} \mathrm{C}$ and $\delta^{18} \mathrm{O}$ sequences has been interpreted as evidence of seasonal movements of the herds towards different ecological niches, for example from altitudinal locations in the mountains to the valley basins (Tornero et al. 2016a, 2016b, 2018; Makarewicz et al. 2017; Isaakidou et al. 2019; Tejedor-Rodríguez et al. 2021).

In all three cases of El Mirador sheep, the relationship between the two curves shows that the periods of highest humidity (lowest carbon values) coincide with ones when the oxygen curve begins to fall from the highest to the lowest values, i.e. periods when temperatures decreased (Fig. 3), that is the fall months (Fig. 5). Based on the seasonality of occupations, it is unlikely that these $\delta^{13} \mathrm{C}$ and $\delta^{18} \mathrm{O}$ patterns were due to seasonal movements of the herds at El Mirador. The pastures of the Sierra de Atapuerca or the neighbouring Sierra de la Demanda were traditionally occupied in the summer by those shepherds who opted for seasonal displacement of their herds for food maintenance. This is due to the altitude of this area (above $1000 \mathrm{~m}$ a.s.l.) and its humid conditions, which support quality pasture in summer, as opposed to other more arid areas of the Iberian Peninsula (Moreno Fernández 1996). However, in levels MIR 16, MIR15 and MIR14, where individuals Ovis 02,06 and 07 came from, there is evidence of occupation of the fold at least in winter, and also in autumn, in the last case. In other words, presence inside the cave has been confirmed during seasons that, a priori, would not be optimal if seasonal movements of the flock were being carried out.

\section{Economic use of sheep}

Controlling the seasonality of sheep breeding has a direct impact on their economic use. The shorter the anoestrous phase of ewes, the greater the availability of resources from the herd, especially milk (Gómez-Brunet et al. 2012).

At El Mirador, mortality profiles of sheep and goats have been used to understand herd management (Fig. 2) because the high degree of fracture of the remains and the abundance of immature individuals makes it difficult to distinguish between the two species. In addition to the high proportion of perinatal individuals (Martín et al. 2016), there are adults (>24 
months), juveniles (6-24) and infants (1-6 months) at El Mirador (Fig. 2). This mortality pattern has been linked to an economic system in which the exploitation of milk is prioritised over the specific use of meat (Martín et al. 2016). Perinatal deaths are likely the result of natural mortality (episodes of stress, disease, adverse cold/humidity conditions, etc.), but this does not mean that these phenomena are not taken advantage of for dairy or meat consumption by humans. We have found evidence of processing and consumption in foetal and neonatal meat (Martín et al. 2016).

According to this interpretation, the birth of most individuals at the end of winter/early spring would allow for the development of this economic system. Births would coincide with the beginning of the temperature rise in these latitudes that would favour the access to grasses of quality, for both females and their young. Thus, lambs could incorporate vegetables into their diet at 4 or 5 weeks, facilitating the human use of at least part of the milk production of females (Cambero 1997; Folch et al. 2007). Further, adequate access to pastures would favour the ewes' milk production since it requires that they be in a good nutritional state (Hammond 1940; Cambero 1997; Hjort and Dahl 1991). Finally, it would allow both females and calves to be prepared for possible summer displacements that may also require significant energy expenditure for these animals (Violant i Simorra 2001; Miralles and Tutusaus 2005).

The presence of two individuals whose birth season was in autumn was also documented in this study. These births may have been related to an attempt to optimise herd maintenance and milk production throughout the year by the shepherd. As discussed earlier, autumn-born individuals came from 5 th millennium cal BCE occupations (MIR14 and MIR15). In addition, in MIR15 level, two individuals were sampled: aforementioned lamb, born in autumn and another born at the beginning of February. This could be a phenomenon of double births in a single year or even a cycle of three births in 2 years, which has also been documented in ethnographic studies (Cambero 1997). These same studies show the benefits of this practice of diversifying the seasonality of births, especially those which promote a cycle of three births in two years, as it is safer for the maintenance of the herd (especially if it is extensive) in various ways. Firstly, it allows the weakest or less prolific females to forgo a birthing cycle. Secondly, it benefits the reserve of lambs that have just reached puberty (around 6 months) and which have difficulty going into heat for the first time (Dahl and Hjort 1976; Santiago-Moreno et al. 2004; Folch et al. 2007). Thirdly, this practice would also alleviate any issues in achieving coverage if the lactation anoestrous periods and the seasonal anoestrous periods coincide (Folch et al. 2007). Finally, it helps reduce the risk of overcrowding and problems of neonatal death, as newborns are cared for by the shepherd (Martín-Gómez et al. 2009).

\section{Seasonality of El Mirador occupations}

At El Mirador cave, understanding sheep birth seasonality can elucidate additional information about the duration occupations of the site and herd management. The abundance of foetuses at this site introduces a higher degree of precision of mortality profiles than that observed at other contemporaneous sites. This is because the skeletal development of foetal individuals is less affected by agents that affect the skeleton. This is because the same agents affect foetal individuals less than they do postnatal ones (Martín and García-González 2015).

The stratigraphic sequence of fumier deposits reflects a pattern of cyclical occupation with periods of abandonment. Periodic dung burning was necessary to keep the space clean. Key questions remain regarding the duration of each of the occupations and whether burning took place immediately before or after the departure of the herd. Ethnographic studies have documented burning taking place in late summer or early autumn, a few months after the herd abandonment of the sheepfolds (Brochier et al. 1992; Acovitsioti-Hameau et al. 2000; Brochier 2002), which allowed dung and urine to dry prior to burning (Vergès 2011; Vergès et al. 2016b).

The fumier levels of El Mirador cave correspond to events limited in time and the materials recovered from each of them are those that were deposited during the occupation or set of occupations that took place between one burning process and another (Vergès et al. 2016a).

This isotopic study, in combination with data provided from the mortality profiles (Fig. 6) (Martín 2015), showed a general trend of cave occupation from winter to early summer. Likewise, at some levels (MIR16, MIR19 and MIR24), individuals were present during or at the end of summer. The MIR14 level, with autumnal birth seasonality, presented an occupation of late summer and early autumn and during the winter months (Fig. 6). The MIR15 level, with evidence of autumn and spring births, presented an almost annual occupation (Fig. 6).

In the rest of the levels from the 6th and 5th millennia cal $\mathrm{BCE}$, on which it has not been possible to perform isotopic analyses, occupations were also observed in the months immediately before and after births, regardless of whether these occurred in spring or in autumn.

Thus, the cave was occupied by the herds at different times of the year, although there was a preference for spring and winter months, evidenced by the abundance of foetal and neonatal individuals and births that occurred in the winter-early spring. These characteristics have all been documented in current sheepfolds (Violant i Simorra 2001).

Although, sheepfold summer occupations were less intense, there is other evidence of the cave's use by humans during the summer. Cereal harvesting in these latitudes takes place during the early-mid summer. Based on the remains of 
Fig. 6 Seasonality of the occupation of the cave of El Mirador at different levels, determined from the data provided the age-at-death of domestic caprines under 24 months. Table A. Seasonality provided by individuals born in late winter/ spring. Table B. Seasonality provided by individuals born in autumn.

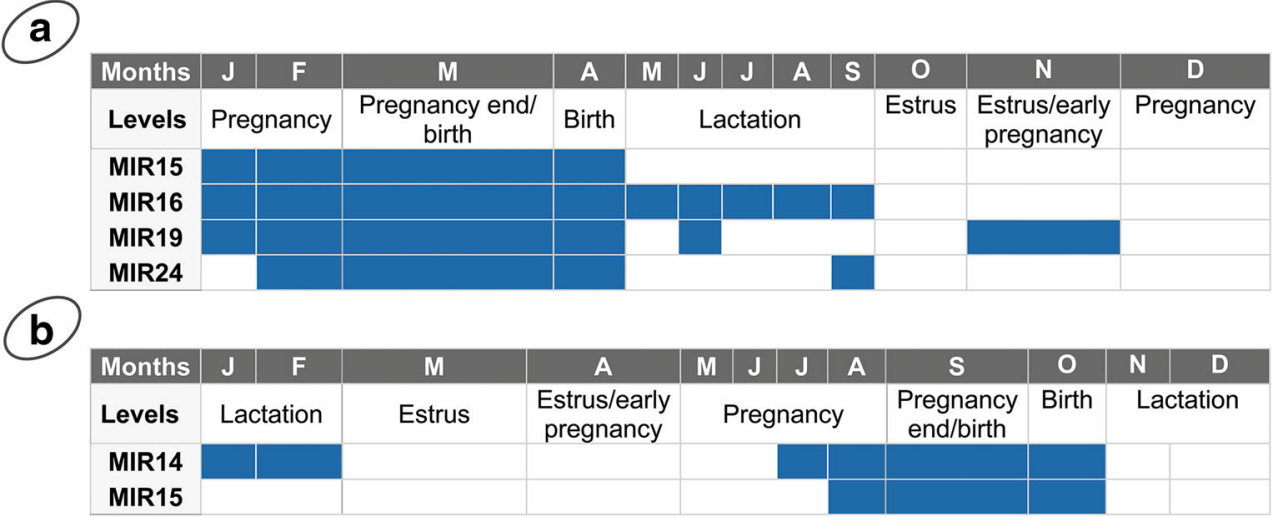

rachis, herringbone bases, or phytolites of cereals documented from the levels from the 6th and 5th millennia cal BCE, it appears that cereal was cleaned inside the cave (Rodríguez and Buxó 2008; Rodríguez et al. 2016).

The less intense occupation of the cave as a sheepfold in the summer could have been because herds grazed in the surrounding areas to take advantage of the good weather and the availability of pasture. This practice would have also made it possible to leave the sheepfold temporarily so that the dung accumulation could be dried on the cave and burned.

The discontinuous but constant presence of sheep in the cave and their surroundings throughout the year could also be an indication of the absence of seasonal long displacements. In favour of this hypothesis are the data provided by isotopic studies. The inverse relationship between $\delta^{13} \mathrm{C}$ and $\delta^{18} \mathrm{O}$ values that show possible vertical movements of the herds was not clearly observed in the specimens studied (Tornero et al. 2016b; Makarewicz et al. 2017; Tornero et al. 2018). However, regional isotopic studies would be necessary to confirm these data, considering the great influence that rainfall has on $\delta^{13} \mathrm{C}$ and $\delta^{18} \mathrm{O}$ sequences (Tornero et al. 2018).

In the Mediterranean context, caves, especially sheepfold caves and caves located in inland/mountain areas, have been interpreted as seasonal settlements, related to livestock movements and the annual search for pasture. By contrast, open-air settlements, usually located in the lowlands, have been interpreted as permanent occupations (Helmer et al. 2005a, 2005 b). However, recent studies located in northeastern Iberia and the Pyrenean region suggest possible multiple patterns of occupation (Antolín et al. 2018), based on agricultural and livestock evidence and statistical criteria. This would have been a much more complex system, beyond the duality of cave/mountain/livestock/seasonality and open-air site/lowland/agriculture/stability. These first Neolithic occupations of the Iberian Peninsula would have been organised economically according to the characteristics of the terrain (climatic, altitudinal, environmental, etc.). Thus, occupations of cave sites were likely to be have been permanent, even in the Pyrenean environment, such as Chaves (640 m a.s.l.) and
Espluga de la Puyascada (1300 m a.s.1.) (Sierra et al. 2019). Chaves also presents possible evidence of fumier deposits and use as a sheepfold (Utrilla and Laborda 2018). By contrast, seasonal use of other sheepfold caves has been documented, such as at Coro Trasito (Clemente-Conte et al. 2016) and Els Trocs (Rojo-Guerra et al. 2014).

Given the data presented on El Mirador cave, the first Neolithic occupations follow this same pattern showing a certain continuity. This would be in accordance with the compatibility of agricultural and livestock practices.

\section{Conclusions}

Sheep have been the main domestic animal raised in the Iberian Peninsula since the arrival of a husbandry economy around the second half of the 6th millennium BCE. In this paper, we presented a study of the management of domestic sheep in the inland of Iberian Peninsula during the early stages of livestock practices, during the 6th and 5th millennia cal BCE. For this purpose, an isotopic study $\left(\delta^{18} \mathrm{O}\right.$ and $\left.\delta^{13} \mathrm{C}\right)$ of the bioapatite from the dental enamel of sheep of El Mirador cave was conducted.

Results support the rapid adoption and adaptation of sheep in the inland of the Iberian Peninsula that has been proposed by other authors using different criteria with El Mirador providing one the first isotopic evidence. The sheep found there were adapted to a colder and rainier climate than both the Mediterranean climate of the Near East domestication nucleus and the initial reception area of these new practices in the Iberian Peninsula.

$\delta^{18} \mathrm{O}$ values show that the sheep of El Mirador cave were born mainly in late winter and early spring, following the same pattern as those at other European and Near East Neolithic sites. The duration of the birth season was relatively short at El Mirador cave (2.64 months). This could have been related to the control of reproduction by shepherds with the objective of concentrating births and favouring other tasks related to the mixed farming economy. 
This same control could have been related to the presence of two individuals, from the occupations of the 5th millennium (ca. 4400-4200 cal BCE) born in autumn, outside the period set by photoperiodic control. This phenomenon may have been related to a second phase of the adoption of husbandry in the Iberian Peninsula, during the 5th millennium, when there was a diversification in the exploitation of the species (Saña et al. 2013). A larger sample size would be required to obtain additional isotopic information about this process.

Ranges of variation in $\delta^{13} \mathrm{C}$ and $\delta^{18} \mathrm{O}$ sequences indicate a probable year-round feeding of the herd in the areas surrounding the cave. In addition, the low $\delta^{13} \mathrm{C}$ values in some individuals could be linked to the use of woody fodder to feed the herd; at El Mirador, this has already been supported by archaeobotanical studies. These data are in line with those obtained on the seasonal occupation of the cave. The combination of the mortality profiles and the results of the isotopic analyses indicate that the cave would have been used intensively for a large portion of the year. This supports recent studies that argue for abandoning the traditional idea of defining caves as sites for seasonal use.

Supplementary Information The online version contains supplementary material available at https://doi.org/10.1007/s12520-021-01355-8.

Acknowledgements We would like to thank the El Mirador cave excavation team. The work was developed as part of the projects CGL201565387-C3-1P and PGC2018-093925-B-C32 (Spanish MINECO/ FEDER), 2017-SGR 836 and 2017 SGR-00011 (AGAUR, Generalitat de Catalunya). P.M. was supported by a postdoctoral grant from the Juan de la Cierva Subprogramme (FJCI-2016-29045), with financial sponsorship from the Spanish Ministry of Economy, Industry and Competitiveness.

\section{References}

Acovitsioti-Hameau A, Brochier JÉ, Hameau P (2000) Témoignages et marqueurs du pastoralisme actuel en Grèce: une ethnographie des gestes et des restes et les applications archéologiques corrélées. Ethnologhia 6-7:93-135

AEMET (2011) Iberian Climate Atlas. Agencia Estatal de Meteorología, Madrid.

Allué E, Euba I (2008) Los datos antracológicos de la secuencia neolítica de El Mirador (Atapuerca, Burgos): un estudio sobre el medio vegetal y la explotación de las especies vegetales leñosas. In: Hernández Pérez MS, Soler Díaz JA, López Padilla JA (eds) IV Congreso del Neolítico Peninsular, 27-30 de noviembre de, vol 2006. Museo Arqueológico de Alicante-MARQ, Alicante, pp 345-352

Allué E, Vernet JL, Cebrià A (2009) Holocene vegetational landscapes of NE Iberia: charcoal analysis from Cova de la Guineu, Barcelona, Spain. The Holocene 19:765-773

Altuna J, Mariezkurrena K (2009) Tipos de cabañas ganaderas durante el Neolítico del País Vasco y zonas próximas. Archaeofauna 18:137157

Angelucci DE, Boschian G, Fontanals M, Pedrotti A, Vergès JM (2009) Shepherds and karst: the use of caves and rock-shelters in the
Mediterranean region during the Neolithic. World Archaeol 41: 191-214

Antolín F, Navarrete V, Saña M, Viñerta A, Gassiot E (2018) Herders in the mountains and farmers in the plains? A comparative evaluation of the archaeobiological record from Neolithic sites in the eastern Iberian Pyrenees and the southern lower lands. Quat Int 484:75-93

Arias P (2007) Neighbours but diverse: social change in north-west Iberia during the transition from the Mesolithic to the Neolithic (55004000 cal BC). Proc Br Acad 144:53-71

Badal E (1999) El potencial pecuario de la vegetación mediterránea: las cuevas Redil. In: Actes del II Congrés del Neolític a la Península Ibèrica. Universitat de Valencia, Valencia, pp 69-76

Balasse M, Ambrose SH, Smith AB, Price TD (2002) The Seasonal Mobility Model for Prehistoric Herders in the South-western Cape of South Africa Assessed by Isotopic Analysis of Sheep Tooth Enamel. J Archaeol Sci 29 (9):917-932

Balasse M, Obein G, Ughetto-Monfrin J, Mainland I (2012a) Investigating seasonality and season of birth in past herds: a reference set of sheep enamel stable oxygen isotope ratios. Archaeom 54: 349-368

Balasse M, Loïc Boury J, Tresset A (2012b) Stable isotope insights $\left(\delta^{18} \mathrm{O}\right.$, $\delta^{13} \mathrm{C}$ ) into cattle and sheep husbandry at Bercy (Paris, France, 4th millennium $\mathrm{BC}$ ): birth seasonality and winter leaf foddering. Environ Archaeol 17(1):29-44

Balasse M, Tresset A, Bălăsescu A, Blaise E, Tornero C, Gandois H, Fiorillo D, Nyerges NA, Frémondeau D, Banffy E, Ivanova M (2017) Animal board invited review: sheep birth distribution in past herds: a review for prehistoric Europe (6th to 3rd millennia BC). Animal 11(12):2229-2236

Balasse M, Renault-Fabregon L, Gandois H, Fiorillo D, Gorczyk J, Bacvarov K, Ivanova M (2020) Neolithic sheep birth distribution: results from Nova Nadezhda (sixth millennium BC, Bulgaria) and a reassessment of European data with a new modern reference set including upper and lower molars. J Archaeol Sci 118:105139

Baldellou Martínez V (2011) La cueva de Chaves (Bastarás-Casbas, Huesca). Saguntum Extra 12:141-145

Bañuls S, Martín Rodríguez P, López-García JM, Morales JI, CuencaBescós G, Vergès JM (2017) Human impact on small-mammal diversity during the middle- to late-Holocene in Iberia: the case of El Mirador cave (Sierra de Atapuerca, Burgos, Spain). The Holocene 27:1067-1077

Bañuls-Cardona S, López-García JM (2016) Climatic and environmental conditions from the Neolithic to the Bronze Age (7000-3000 BP) in the Iberian Peninsula assessed using small-mammal assemblages. C R Palevol 15:958-967

Beeching A, Berger JF, Brochier JE, Ferber F, Helme D, Sidi Maamar H (2000) Chasséens: agriculteurs ou éleveurs, sédentaires ou nomades?. Quels types de milieu, d'économies et de societies? In: Rencontres méridionales de Préhistorie récente. Session, Toulouse, pp 59-79

Bender MM (1971) Variations in the ${ }^{13} \mathrm{C} /{ }^{12} \mathrm{C}$ ratios of plants in relation to the pathway of photosynthetic carbon dioxide fixation. Phytochem 10:1239-1244

Bernabeu J, Molina L, Esquembre MA, Ramón J, Boronat JD (2009) La cerámica impresa mediterránea en el origen del Neolítico de la península Ibérica. In: De Méditerranée et d'ailleurs... Mélanges offerts à Jean Guilaine. Archives d'Écologie Préhistorique, Toulouse, pp 83-95.

Blaise E, Balasse M (2011) Seasonality and season of birth of modern and late Neolithic sheep from south-eastern France using tooth enamel $\delta^{18} \mathrm{O}$ analysis. J Archaeol Sci 38(11):3085-3093

Bréhard S, Beeching A, Vigne JD (2010) Shepherds, cowherds and site function on middle Neolithic sites of the Rhône valley: an archaeozoological approach to the organization of territories and societies. J AnthropolArchaeol 29:179-188 
Brochier JE (2002) Les sediments anthropiques. Méthodes d'étude et perspectives. In: Miskovsky JC (ed) Géologie de la préhistoire : méthodes, techniques, applications. Geopré, Paris, pp 453-473

Brochier JE, Villa P, Giacomarra M (1992) Sheperds and sediments: geoethnoarchaeology of pastoral sites. J Anthropol Archaeol 11:47-102

Bronk Ramsey C (2009) Bayesian analysis of radiocarbon dates. Radiocarb 51(1):337-360

Bronk Ramsey C (2017) Methods for summarizing radiocarbon datasets. Radiocarb 59(2):1809-1833

Bryant JD, Froelich PN, Showers WJ, Genna BJ (1996) Biologic and climatic signals in the oxygen isotopic composition of EoceneOligocene equid enamel phosphate. Palaeogeogr Palaeoclimatol Palaeoecol 126:75-89

Cambero P (1997) Cuaderno de la explotación de ovino. Servicio Agrario de Caja Duero, Salamanca

Cassinello J (2017) Muflon-Ovis orientalis. In: Carrascal LM, Salvador A (eds) Enciclopedia Virtual de los Vertebrados Españoles. Museo Nacional de ciencias naturales, Madrid http://www. vertebradosibericos.org/

Castaños P (2004) Estudio arqueozoológico de los macromamíferos del Neolítico de la Cueva de Chaves (Huesca). Saldvie 4:125-171

Castaños PM (1997) Estudio de la fauna del Cerro I de "Los Castillejos" (Fuente de Cantos, Badajoz). Norba 14:11-45

Cebrià $\mathrm{A}$, Fontanals $\mathrm{M}$, Martín $\mathrm{P}$, Morales JI, Oms FX, RodríguezHidalgo A, Soto M, Vergès JM (2014) Nuevos datos para el Neolítico antiguo en el nordeste de la Península Ibérica procedentes de la Cova del Toll (Moià, Barcelona) y de la Cova de la Font Major (L'Espluga de Francolí, Tarragona). Trab Prehist 71:134-145

Cerling TE, Harris JM (1999) Carbon isotope fractionation between diet and bioapatite in ungulate mammals and implications for ecological and paleoecological studies. Oecol 120:347-363

Clemente-Conte I, Gassiot Ballbè E, Rey Lanaspa J, Antolín F, Obea Gómez L, Viñerta Crespo A, Saña Segui M (2016) Cueva de Coro Trasito (Tella-Sin, Huesca): un asentamiento pastoril en el pirineo central con ocupaciones del Neolítico antiguo y del Bronce medio. In: Congreso Arqueología y Patrimonio Aragonés. Colegio Oficial de Doctores y Licenciados en Filosofía y Letras y en Ciencias de Aragón, Zaragoza, pp 71-80

Cortés Sánchez M, Jiménez Espejo FJ, Simón Vallejo MD, Gibaja Bao JF, Faustino Carvalho A, Martínez-Ruiz F, Rodrigo Gamiz M, Flores JA, Paytan A, López Sáez JA, Peña-Chocarro L, Carrión JS, Morales Muñiz A, Roselló Izquierdo E, Riquelme Cantal JA, Dean RM, Salgueiro E, Martínez Sánchez RM, De la Rubia de Gracia JJ, Lozano Francisco MC, Vera Peláez JL, Llorente Rodríguez L, Bicho NF (2012) The Mesolithic-Neolithic transition in southern Iberia. Quat Int 77:221-234

Cubas M, Lucquin A, Robson HK, Colonese AC, Arias P, Aubry B, Billard C, Jan D, Diniz M, Fernandes R, Fábregas Valcarce R, Germain-Vallée C, Juhel L, de Lombera-Hermida A, Marcigny C, Mazet S, Marchand G, Neves C, Ontañón-Peredo R, RodríguezÁlvarez XP, Simões T, Zilhão J, Craig OE (2020) Latitudinal gradient in dairy production with the introduction of farming in Atlantic Europe. Nat Commun 11:2036

Dahl G, Hjort A (1976) Having herds. Pastoral herd growth and household economy. Libeer Tryck Stockholm, Stockholm.

Davis SJ, Simões T (2016) The velocity of Ovis in prehistoric times: the sheep bones from Early Neolithic Lameiras, Sintra, Portugal. In: Diniz M, Neves C, Martins A (eds) O Neolítico em Portugal antes do horizonte 2020: perspectivas em debate. Associação dos Arqueólogos Portugueses, Lisboa, pp 51-66

Debono Spiteri C, Gillis RE, Roffet-Salque M, Castells Navarro L, Guilaine J, Manen C, Muntoni IM, Saña Segui M, Urem-Kotsou D, Whelton HL, Craig OE, Vigne JD, Evershed R (2016) Regional asynchronicity in dairy production and processing in early farming communities of the northen Mediterranean. PNAS 114(1):E105E106
Delhon C, Martin L, Argant J, Thiébault S (2008) Shepherds and plants in the Alps: multi-proxy archaeobotanical analysis of Neolithic dung from "La Grande Rivoire" (Isère, France). J Archaeol Sci 35:29372952

Deniz E, Payne S (1982) Eruption and wear in the mandibular dentition as a guide to ageing Turkish angora goats. In: Wilson B, Grigson C, Payne S Ageing and sexing animal bones from archaeological sites. BAR British Series, 109, Oxford, pp 155-207.

Drucker DG, Bridault A, Hobson KA, Szuma E, Bocherens H (2008) Can carbon-13 in large herbivores reflect the canopy effect in temperate and boreal ecosystems? Evidence from modern and ancient ungulates. Palaeogeogr Palaeoclimatol Palaeoecol 266 (1-2):69-82

Ducos P (1968) L'origine des animaux domestiques en Palestine. Bordeaux, Travaux de l'Institut Préhistorique de Bordeaux, 6, Bordeaux.

Dwyer C (2008) The welfare of sheep. Springer

Esquembre-Bebiá JA, Boronat Soler J, Jover Maestre FJ, Molina Hernández FJ, Luján Navas A, Fernández López de Pablo J, Martínez Valle R, Iborra Eres MP, Ferrer García C, Ruíz Pastor R, Ortega Pérez JR (2008) El yacimiento neolítico del Barranquet de Oliva (Valencia). In Hernández Pérez MS, Soler Díaz JA., López Padilla J.A. (eds) IV Congreso del Neolítico Peninsular: 27-30 de noviembre de 2006. Museo Arqueológico de Alicante, Diputación de Alicante, Alicante, pp 183-190.

Euba I, Allué E, Burjachs F (2016) Wood uses at El Mirador Cave (Atapuerca, Burgos) based on anthracology and dendrology. Quat Int 414:285-293

Expósito I, Burjachs F, Vergès JM (2017) Human trace on the landscape during the Holocene at El Mirador Cave (Sierra de Atapuerca, Spain): The palynological evidence. The Holocene 27:1201-1213

Fernández-Eraso J (1989) Abrigo de Peña Larga (Cripán). V Campaña de excavaciones Arkeoikuska: Investigación arqueológica 1989:21-27

Fernández-Eraso J, Mujika-Alustiza JA (2013) La estación megalítica de la Rioja Alavesa: cronología, orígenes y ciclos de utilización. Zephyrus LXXI:89-106

Fernández-Eraso J, Mujika-Alustiza JA, Zapata-Peña L, IriarteChiapusso MJ, Polo-Díaz A, Castaños P, Tarriño-Vinagre A, Cardoso S, Sesma-Sesma J, García-Gazolaz J (2015) Beginnings, settlement and consolidation of the production economy in the Basque región. Quat Int 364:162-171

Fernández-Posse MD (1980) Los materiales de la Cueva del Aire de Patones (Madrid). Noticiario Arqueológico Hispánico 3:189-236

Folch J, Alabart JL, Echegoyen E, Martí JI, Sánchez P, Fantova E, Roche A (2007) Manejo reproductivo de la oveja Rasa Aragonesa. Preparación de las ovejas destinades a la inseminación artificial. Grupo Consolidado de Investigación Aplicada sobre Producción de Ovino de Carne. Gobierno de Aragón:71-101

Fontanals M, Euba I, Morales JI, Oms FX, Vergès JM (2008) El asentamiento litoral al aire libre de El Cavet (Cambrils, Tarragona). In: Hernández Pérez MS, Soler Díaz JA, López Padilla JA (eds) IV Congreso del Neolítico Peninsular, 27-30 de noviembre de, vol 2006. Museo Arqueológico de AlicanteMARQ, Alicante, pp 168-175

Forcada F, Abecia JA, Sierra I (1992) Seasonal changes in oestrus activity and ovulation rate in Rasa Aragonesa ewes maintained at two different body condition levels. Small Rumin Res 8:313-324

Fraser RA, Grün R, Privat K, Gagan MK (2008) Stable-isotope microprofiling of wombat tooth enamel records seasonal changes in vegetation and environmental conditions in eastern Australia. Paleogeogr Palaeoclimatol Palaeoecol 269:66-77

Fricke HC, O'Neil JR (1996) Inter-and intra-tooth variation in the oxygen isotope composition of mammalian tooth enamel phosphate: implications for palaeoclimatological and palaeobiological research. Paleogeogr Palaeoclimatol Palaeoecol 126:91-99

García-Martínez de Lagrán I (2013) La neolitización de la Meseta Norte y de la Alta y Media Cuenca del Ebro (España): premisas teóricas, 
análisis del registro y planteamiento de hipótesis. Zephyrus, LXXIII: 83-107.

García-Puchol O, Díez Castillo AA, Pardo-Godó S (2017) Alternative stories of agricultural origins: the Neolithic spread in the Iberian Peninsula. In: Salazar-García DC (ed) García-Puchol O. Times of Neolithic transition along the Western Mediterranean, Springer USA, pp 69-100

Gat JR (1980) The isotopes of hydrogen and oxygen in precipitation. In: Fritz P, Fontes JC (eds) Handbook of environmental isotope geochemistry, vol 1. Elsevier Scientific, Ambsterdam, pp 21-38

Gillis R, Chaix L, Vigne JD (2011) An assessment of morphological criteria for discriminating sheep and goat mandibles on a large prehistoric archaeological assemblage (Kerma, Sudan). J Archaeol Sci 38:2324-2339

Gómez-Brunet A, Santiago-Moreno J, Toledano-Diaz A, LópezSebastián (2012) Reproductive seasonality and its control in Spanish sheep and goats. Tropical and Subtropical Agroecosystems 15:S47-S70

Gourichon L (2004) Faune et saisonnalité: l'organisation temporelle des activités de subsistence de l'Epipaléolithique et le Néolithique précéramique du Levant nord (Syrie). Doctoral thesis. Université Lumière-Lyon 2, Lyon.

Green DR, Green GM, Colman AS, Bidlack FB, Tafforeau P, Smith TM (2017) Synchrotron imaging and Markov Chain Monte Carlo reveal tooth mineralization patterns. PLoS One 12:e186391

Greenfield HJ, Arnold ER (2008) Absolute age and tooth eruption and wear sequences in sheep and goat: determining age-at-death in zooarchaeology using modern control sample. J Archaeol Sci 35: 836-849

Hadjíkoumis A, Vigne J-D, Simmons A, Guilaine J, Fiorillo D, Balasse M (2019) Autumn/winter births in traditional and pre-pottery Neolithic caprine husbandry in Cyprus: evidence from ethnography and stable isotopes. J Anthropol Archaeol 53:102-111

Hafez ESE (1952) Studies on the breeding season and reproduction of the ewe. Part I The breeding season in different environments Part II The breeding season in one locality J Agric Sci 42:13-231

Halstead P (1998) Mortality models and milking: problems of uniformitarism, optimality and equifinality reconsidered. Anthropozoologica 27:3-20

Halstead P, Collins P, Isaakidou V (2002) Sorting the sheep from the goats: morphological distinctions between the mandibles and mandibular teeth of adult Ovis and Capra. J Archaeol Sci 29:545-553

Hammond J (1940) Farm animals. Their breeding, growth and inheritance. Editorial Edward Arnold Ltd., London.

Heaton THE (1999) Spatial, species, and temporal variations in the ${ }^{13} \mathrm{C} /{ }^{12} \mathrm{C}$ ratios of $\mathrm{C}_{3}$ plants: implications for Palaeodiet studies. J Archaeol Sci 26:637-649

Helmer D (2000) Discrimination des genres Ovis et Capra à l'aide des prémolaires inférieures 3 et 4 et interpretation des ages d'abattage: l'exemple de Dikili Tash (Grece). Anthropozoologica 31:29-38

Helmer D, Gourichon L, Sidi Maamar H, Vigne JD (2005a) L'élevage des caprinés néolithiques dans le sud-est de la France: saisonnalité des abattages, relations entre grottes-bergeries et sites de plein air. Anthropozoologica 40:167-189

Helmer D, Gourichon L, Sidi Maamar H, Vigne JD (2005b) L'élevage des caprinés néolithiques dans le sud-est de la France: saisonnalité des abattages, relations entre grottes-bergeries et sites de plein air. Anthropozoologica 40(1):167-189

Hillson S (2005). Theeth. Cambrige Manuals in Archaeology, Cambridge.

Hjort A, Dahl OG (1991) Responsible Man. The Atmaan Beja of Northeastern Sudan. Stockholm Studies in Social Anthropology, Uppsala.

Iborra MP, Martínez R (2009) La fauna de los niveles neolíticos de la Cova de Les Cendres. In: Bernabeu J, Molina L (eds) La Cova de les Cendres (Moraira-Teulada, Alicante). MARQ, Museo Arqueológico de Alicante, Alicante, pp 149-162
Isaakidou V, Styring A, Halstead P, Nitsch E, Stroud E, le Roux P, LeeThorp J, Bogaard A (2019) From texts to teeth: a multi-isotope study of sheep and goat herding practices in the Late Bronze Age ('Mycenaean') polity of Knossos, Crete. J Archaeol Sci Rep 23: $36-56$

Jewell PA, Grubb P (1974) The breeding cycle, the onset of oestrus and conception in Soay sheep. In: Jewell PA, Milner C, Boyd JM (eds) Island survivors: the ecology of the Soay sheep of St. Kilda. Athlone Press, London, pp 224-241

Jones GG (2006) Tooth eruption and wear observed in live sheep from Butser Hill, the Cotswold Farm Park and five farms in the Pentland Hills, UK. In: Deborah D (ed) Recent advances in ageing and sexing animal bones. Oxbow Books, Oxford, pp 155-178

Koch PL, Tuross N, Fogel ML (1997) The Effects of Sample Treatment and Diagenesis on the Isotopic Integrity of Carbonate in Biogenic Hydroxylapatite. J Archaeol Sci 24 (5):417-429

Kohn M (2010) Carbon isotope compositions of terrestrial C3 plants as indicators of (paleo)ecology and (paleo)climate. PNAS 107(46): 19691-19695

Lee-Thorp JA, Sealy JC, van der Merwe NJ (1989) Stable carbon isotope ratio differences between bone collagen and bone apatite, and their relationship to diet. J Archaeol Sci 16:585-599

Lee-Thorp JA, Sealy JC, van der Merwe NJ (1991) Aspects of the chemistry of modern and fossil biological apatites. J Archaeol Sci 18: 343-354

León JM, Zamora R, Puntas J, Delgado JV, Benavente M, Barba C, Lobillo J (2005) Estudio de la prolificidad en la oveja segureña. Resultados preliminares. Arch Zootec 54:443-446

López P, Arnanz A, Uzquiano P, Macías R, Gil P (2003) Informes Técnicos: 1 Paleobotánica. In: Estremera Portela MS (ed) Primeros agricultores y ganaderos en la Meseta Norte: El Neolítico de la Cueva de La Vaquera (Torreiglesias, Segovia), Arqueología en Castilla y León, vol 11. Junta de Castilla y León, Zamora, pp 247 256

Makarewicz CA, Arbuckle BS, Öztan A (2017) Vertical transhumance of sheep and goats identified by intra-tooth sequential carbon $\left(\mathrm{d} 1^{3} \mathrm{C}\right)$ and oxygen $\left(\mathrm{d} 1^{8} \mathrm{O}\right)$ isotopic analyses: evidence from Chalcolithic Köșk Höyük, central Turkey. J Archaeol Sci 86:68-80

Malpaux B, Viguié C, Thiéry J.C, Hemineau P (1996) Contrôle photopériodique de la reproduction. INRA Prod Anim 9 (1): 9-23.

Maluquer J (1960) Bases para el estudio de las culturas metalúrgicas de la Meseta. In: Symposium de Prehistoria Peninsular. Diputación Foral de Navarra. Institución Príncipe de Viana, Pamplona, pp 125-150

Martín P (2015) Caracterización zooarqueológica de las cuevas redil en la Prehistoria de la Meseta Norte: el caso de El Mirador (Sierra de Atapuerca, Burgos). Doctoral thesis. University Rovira i Virgili, Tarragona.

Martín P, García-González R (2015) Identifying sheep (Ovis aries) fetal remains in archaeological contexts. J Archaeol Sci 64:77-87

Martín P, Rosell J, Vergès JM (2009) La gestión de los recursos faunísticos durante el Neolítico en la Sierra de Atapuerca (Burgos): los niveles 19 y 20 de la Cueva del Mirador. Trab Prehist 62:77-92

Martín P, García-González R, Nadal J, Vergès JM (2016) Perinatal ovicaprine remains and evidence of shepherding activities in Early Holocene enclosure caves: El Mirador (Sierra De Atapuerca, Spain). Quat Int 414:316-329

Martín-Gómez S, De la Fuente FL, Gil Rubio MJ, Herrera Yenes E, Requejo Fernández JA, Ruiz Mantecón A (2009) La estacionalidad de los sistemas reproductivos y su influencia en la productividad y el predio medio anual de la leche. PR: pequeños rumiantes 10:26-30

Mateu I (1993) A revised list of the European C4 list. Photosynthetica 26(3):323-331

Milhaud G, Nezit J (1991) Développement des molaires chez le Mouton: Étude morphologique, radiographique et microdurométrique. Recl Med Vet 167:121-127 
Miracle P (2006) Neolithic shepherds and their herds in the Northern Adriatic Basin. In: Serjeatson D, Field D (eds) Animals in the neolithic of Britain and Europe. Oxbow Books, Oxford, pp 63-94

Miracle P, Forenbaher S (2005) Neolithic and bronze-age herders of Pupićina Cave, Croatia. J Field Archaeol 30:255-281

Miralles F, Tutusaus J (2005) Mil anys pels camins de l'herba: el llegat d'un món que s'acaba. Efadós, Tarragona.

Morales A, Martín S (2003) Informe sobre los restos de mamíferos recuperados en los niveles neolíticos de la Cueva de La Vaquera. In: Estremera MS (ed) Primeros agricultores y ganaderos en la Meseta Norte: El Neolítico de la Cueva de La Vaquera (Torreiglesias, Segovia). Junta de Castilla y León, Zamora, pp 257-303

Moreno Fernández JR (1996) La ganadería trashumante en La Rioja 1752-1865. Una revisión bibliográfica y cuantitativa Brocar 20: 277-302

Navarrete V, Tornero C, Balasse M, Saña M (2019) Food management of early introduced caprine and bovine herds in the early Neolithic site of La Draga (Banyoles): an isotopic approach. Int J Osteoarchaeol 29:986-998

Nikolov V (2007) Problems of the early stages of the Neolithization in the Southeas Balkans. In: Spataro M, Biagi P (eds) A short walk through the Balkans: the first farmers of the Carpathian Basin and adjacen regions. Società per la Preistoria e Protostoria della regione FriuliVenezia Giulia, Trieste, pp 183-188

Oms FX, López-García JM, Mangado X, Martín P, Mendiela S, Morales JI, Pedro M, Rodríguez A, Rodríguez-Cintas A, Yubero M (2013) Hàbitat en cova i espai pels ramas ca. 6200-6000 BP: La Cova Colomera (Prepirineu de Lleida) durant el Neolític Antic. Saguntum (PLAV) 45:25-38

Oms FX, Esteve X, Mestres J, Martín P, Martins H (2014) La neolitización del nordeste de la Península Ibérica: datos radiocarbónicos y culturales de los asentamientos al aire libre del Penedès. Trab Prehist 71:42-55

Oms FX, Martín A, Esteve X, Mestres J, Morell B, Subirà ME, Gibaja JF (2016) The Neolithic in the Northeast Iberia: chronocultural phases and ${ }^{14} \mathrm{C}$. Radiocarb 58(2):291-309

Owen J, Fayez I, Marai M (1994). Nuevas tecnicas de producción ovina. Acribia, Zaragoza.

Payne S (1973) Kill-off patterns in sheep and goats: the mandibles from Așvan Kale. Anatol Stud 23:281-303

Payne S (1985) Morphological distinctions between the mandibular teeth of young sheep, ovis and goats, capra. J Archaeol Sci 12:139-147

Penalba MC (1994) The history of the holocene vegetation in Northern Spain from pollen analysis. J Ecol 4:815-832

Peña-Chocarro L, Pérez-Jordà G, Morales J (2018) Crops of the first farming communities in the Iberian Peninsula. Quat Int 470:369-382

Pérez-Obiol R, Jalut G, Julià R, Pèlachs A, Iriarte MJ, Otto T, HernándezBeloqui (2011) Mid-Holocene vegetation and climatic history of the Iberian Peninsula. The Holocene 21 (1): 75-93.

Poulton AL, Robinson TJ (1987) The response of rams and ewes of three breeds to artificial photoperiod. J Reprod Fertil 79:609-626

Ramos E (2009) Sistemas agrosilvopastorales en el sudeste ibérico: una alternativa sostenible a los monocultivos leñosos de secano. Doctoral thesis, University of Granada, Granada.

Represa D (1998) Pastores de las Peñas de Cervera. Rev Folk 211:3-25

Rodríguez A, Buxó R (2008) Cultivos y alimentación vegetal durante el Neolítico en la Cueva de El Mirador (Sierra de Atapuerca, Burgos). In: Hernández Pérez MS, Soler Díaz JA, López Padilla JA (eds) IV Congreso del Neolítico Peninsular, 27-30 de noviembre de, vol 2006. Museo Arqueológico de Alicante-MARQ, Alicante, pp 317-325

Rodríguez A, Allué E, Buxó R (2016) Agriculture and livestock economy among prehistoric herders based on plant macro-remains from $\mathrm{El}$ Mirador (Atapuerca, Burgos). Quat Int 414:272-284
Rojo-Guerra M, Arcusa Magallón H, Peña Chocarro L, Royo Guillén JI, Tejedor Rodríguez C, García Martínez de Lagrán I, Garrido Pena R, Moreno-García M, Pimenta C, Mazzuco N, Gibaja Bao JF, Pérez Jordá G, Jiménez Jiménez I, Iriarte E, Alt KW (2014) Los primeros pastores trashumantes de la Alta Ribagorza. In: Sobrarbe antes de Sobrarbe: pinceladas de historia de los Pirineos. Centro de Estudios de Sobrarbe, Instituto de Estudios Altoaragoneses, Sobrarbe, pp $127-151$

Rose HJD, Bryant MJ (2003) Seasonality of reproduction in sheep. Small Rumin Res 48:155-171

Saña M (2011) La gestió dels recursos animals. In: Tarrús J, Bosch A, Chichilla J (eds) El poblat lacustre del Neolític antic de la Draga. Excavacions 2000-2005. Generatlitat de Catalunya, Barcelona, pp $177-212$

Saña M (2013) Domestication of animals in the Iberian Peninsula. In: Colledge S, Conolly J, Dobney K, Manning K, Shennan S (eds) The origins and spread of domestic animals in Southwest Asia and Europe. Left Coast Press, California, pp 195-220

Saña M, Antolín F, Alcántara R, Sierra A, Tornero C (2020) Interpretating domesticates: earliest farming experiences in the Iberian Peninsula. In: Gron KJ, Sorensen L, Rowley-Conwy P (eds) Farmers at the Frontier: a pan European perspective on Neolithisation. Oxbow Bookx, Oxford and Philadelphia, pp 161176

Santiago-Moreno J, López-Sebastián A, González-Bulnes A, GómezBrunet A, Chemineau P (2000) Seasonal changes in ovulatory activity, plasma prolactin, and melatonin concentration, in Mouflon (Ovis gmelini musimon) and manchega (Ovis aries) ewes. Reprod Nutr Dev 40:421-430

Santiago-Moreno J, Toledano-Díaz A, Gómez-Brunet A, LópezSebastián A (2004) El Muflón europeo (Ovis orientalis musimon SCHREBER, 1972) en España: consideraciones históricas, filogenéticas y fisiología reproductiva. Galemys 16: 3-20.

Santiago-Moreno J, Gómez-Brunet A, Toledano-Díaz A, Picazo R, González-Bulnes A, López-Sebastián A (2006) Seasonal endocrine changes and breeding activity in Mediterranean wild ruminants. Reprod Domest Anim 41(2):72-81

Seguí JR (1999) Traditional pastoralism in the Fageca and Famorca villages (Mediterranean Spain): an Ethnoarchaeological approach. Universidad de Leicester, Leicester, Docthoral thesis

Shahack-Gross R, Tchernov E, Luz B (1999) Oxygen isotopic composition of mammalian skeletal phosphate from the Natufian Period, Hayonim Cave, Israel: diagenesis and paleoclimate. Geoarchaeol: Int J 14:1-13

Siegel S, Castellan NJ (1988) Nonparametric statistics for the behavioural sciences. McGraw Hill, New York

Sierra A, Bréhard S, Montes L, Utrilla P, Saña M (2019) Sheep exploitation and husbandry in first farming societies: from production to consumption in Central Pyrenees in the Early Neolithic. Archaeol Anthropol Sci 11:5813-5829

Solecki RS (1979) Contemporary Kurdish winter-time inhabitants of Shanidar Cave, Iraq. World Archaeol 10:318-330

Tejedor-Rodríguez C, Moreno-García M, Tornero C, Hoffmann A, García-Martínez de Lagrán I, Arcusa-Magallón H, Garrido-Pena R, Royo-Guillén JI, Díaz-Navarro S, Peña-Chocarro L, Alt KW, Rojo-Guerra M (2021) Investigating Neolithic caprine husbandry in the Central Pyrenees: insights from a multi-proxy study at Els Trocs cave (Bisaurri, Spain). PlosOne 16(1):e0244139

Terradas-Batlle X, Piqué R, Palomo A, Bosch A, Buxó R, Chinchilla J, Saña Seguí M, Tarrús J, Bogdanovic I, Rosillo R (2015) Darreres intervencions arqueològiques al poblat neolític de La Draga i a l'estany de Banyoles (Banyoles, Pla de l'Estany). Tribuna d'Arqueologia 2012-2013:33-47

Thiébault S (2005) L'apport du fourrage d'arbre dans l'élevage depuis le Néolithique. Antropozoologica 40:95-108 
Tornero C, Bălăşescu A, Ughetto-Monfrin J, Voinea V, Balasse M (2013) Seasonality and season of birth in early Eneolithic sheep from Cheia (Romania): methodological advances and implications for animal economy. J Archaeol Sci 40:4039-4055

Tornero C, Balasse M, Bălășescu A, Chataigner C, Gasparyan B, Montoya C (2016a) The altitudinal mobility of wild sheep at the Epigravettian site of Kalavan 1 (Lesser Caucasus, Armenia): evidence from a sequential isotopic analysis in tooth enamel. J Hum Evol 97:27-36

Tornero C, Balasse M, Molist M, Saña M (2016b) Seasonal reproductive patterns of early domestic sheep at Tell Halula (PPNB, Middle Euphrates Valley): evidence from sequential oxygen isotope analyses of tooth enamel. J Archaeol Sci Rep 6:810-818

Tornero C, Aguilera M, Ferrio JP, Arcusa H, Moreno-García M, GarcíaReig S, Rojo-Guerra M (2018) Vertical sheep mobility along the altitudinal gradient through stable isotope analyses in tooth molar bioapatite, meteoric water and pastures: a reference from the Ebro valley to the Central Pyrenees. Quat Int 484:94-106

Tornero C, Balasse M, Bréhard S, Carrère I, Fiorillo D, Guilaine J, Vigne JD, Manen C (2020) Early evidence of sheep lambing de-seasoning in the Western Mediterranean in the sixth millennium BCE. Sci Rep 10:12798

Utrilla P, Laborda R (2018) La cueva de Chaves (Bastarás, Huesca): 15 000 años de ocupación prehistórica. Trab Prehist 75:248-269

Valdez R (2008) Ovis orientalis. The IUCN Red List of Threatened Species 2008: e.T1539A5076068

van der Merwe NJ, Medina E (1991) The canopy effect, carbon isotope ratios and foodwebs in Amazonia. J Archaeol Sci 18:249-259

Vergès JM (2011) La combustión del estiércol: aproximación experimental a la quema en montón de los depósitos de redil. In: Morgado A, Baena J, García D (eds) La investigación Experimental aplicada a la Arqueología. Universidad de Granada, Ronda, pp 325-330

Vergès JM, Allué E, Fontanals M, Morales JI, Martín P, Carrancho A, Expósito I, Guardiola M, Lozano M, Marsal R, Oms X, Euba I,
Rodríguez A (2016a) El Mirador cave (Sierra de Atapuerca, Burgos, Spain): A whole perspective. Quat Int 414:236-243

Vergès JM, Burguet-Coca A, Allué E, Expósito I, Guardiola M, Martín P, Morales JI, Burjachs F, Cabanes D, Carrancho A, Vallverdú J (2016b) The Mas del Pepet experimental programme for the study of prehistoric livestock practices: preliminary data from dung burning. Quat Int 414:304-315

Villalba-Mouco V, Utrilla P, Laborda R, Lorenzo JI, Martínez-Labarga C, Salazar-García D (2018) Reconstruction of human subsistence and husbandry strategies from the Iberian Early Neolithic: a stable isotope approach. Am J Phys Anthropol 167(2):257-271

Violant i Simorra R (2001) La vida pastoral al Pallars. Biblioteca Ramon i Violant i Simorra, Tremp

Weinreb W, Sharav Y (1964) Tooth development in sheep. Am J Vet Res 25:891-908

Zapata L, Peña-Chocarro L, Ibáñez JJ, González JE (2003) Ethnoarchaeology in the Moroccan Jebala (Western Rif): wood and dung as fuel. In: Neumann K, Butler A, Kahlheber S (eds) Food, fuels and fields. Progress in African Archaeobotay, Africa Praehistorica, vol 15. Heinrich Barth Institut, Köln, pp 163-175

Zapata L, Peña-Chocarro L, Pérez-Jordá G, Hans-Peter S (2004) Early Neolithic agriculture in the Iberian Peninsula. J World Prehist 18(4): 283-325

Zapata L, Peña-Chocarro L, Pérez Jordá G, Stika HP (2005) Difusión de la agricultura en la Península Ibérica. In: Ontañón Peredo R, GarcíaMoncó Piñeiro C, Arias Cabal P (eds) Actas del III Congreso del Neolítico en la Península Ibérica: Santander, 5 a 8 de octubre de, 2003rd edn. Univesidad de Cantabria, Santander, pp 103-113

Zeder MA, Pilaar SE (2010) Assessing the reliability of criteria used to identify mandibles and mandibular teeth in sheep, Ovis, and goats, Capra. J Archaeol Sci 37:225-242

Publisher's note Springer Nature remains neutral with regard to jurisdictional claims in published maps and institutional affiliations. 


\section{Terms and Conditions}

Springer Nature journal content, brought to you courtesy of Springer Nature Customer Service Center GmbH ("Springer Nature").

Springer Nature supports a reasonable amount of sharing of research papers by authors, subscribers and authorised users ("Users"), for smallscale personal, non-commercial use provided that all copyright, trade and service marks and other proprietary notices are maintained. By accessing, sharing, receiving or otherwise using the Springer Nature journal content you agree to these terms of use ("Terms"). For these purposes, Springer Nature considers academic use (by researchers and students) to be non-commercial.

These Terms are supplementary and will apply in addition to any applicable website terms and conditions, a relevant site licence or a personal subscription. These Terms will prevail over any conflict or ambiguity with regards to the relevant terms, a site licence or a personal subscription (to the extent of the conflict or ambiguity only). For Creative Commons-licensed articles, the terms of the Creative Commons license used will apply.

We collect and use personal data to provide access to the Springer Nature journal content. We may also use these personal data internally within ResearchGate and Springer Nature and as agreed share it, in an anonymised way, for purposes of tracking, analysis and reporting. We will not otherwise disclose your personal data outside the ResearchGate or the Springer Nature group of companies unless we have your permission as detailed in the Privacy Policy.

While Users may use the Springer Nature journal content for small scale, personal non-commercial use, it is important to note that Users may not:

1. use such content for the purpose of providing other users with access on a regular or large scale basis or as a means to circumvent access control;

2. use such content where to do so would be considered a criminal or statutory offence in any jurisdiction, or gives rise to civil liability, or is otherwise unlawful;

3. falsely or misleadingly imply or suggest endorsement, approval, sponsorship, or association unless explicitly agreed to by Springer Nature in writing;

4. use bots or other automated methods to access the content or redirect messages

5. override any security feature or exclusionary protocol; or

6. share the content in order to create substitute for Springer Nature products or services or a systematic database of Springer Nature journal content.

In line with the restriction against commercial use, Springer Nature does not permit the creation of a product or service that creates revenue, royalties, rent or income from our content or its inclusion as part of a paid for service or for other commercial gain. Springer Nature journal content cannot be used for inter-library loans and librarians may not upload Springer Nature journal content on a large scale into their, or any other, institutional repository.

These terms of use are reviewed regularly and may be amended at any time. Springer Nature is not obligated to publish any information or content on this website and may remove it or features or functionality at our sole discretion, at any time with or without notice. Springer Nature may revoke this licence to you at any time and remove access to any copies of the Springer Nature journal content which have been saved.

To the fullest extent permitted by law, Springer Nature makes no warranties, representations or guarantees to Users, either express or implied with respect to the Springer nature journal content and all parties disclaim and waive any implied warranties or warranties imposed by law, including merchantability or fitness for any particular purpose.

Please note that these rights do not automatically extend to content, data or other material published by Springer Nature that may be licensed from third parties.

If you would like to use or distribute our Springer Nature journal content to a wider audience or on a regular basis or in any other manner not expressly permitted by these Terms, please contact Springer Nature at

onlineservice@springernature.com 